\title{
Expanding the Functional Repertoire of CTD Kinase I and RNA Polymerase II: Novel PhosphoCTD-Associating Proteins in the Yeast Proteomet
}

\author{
Hemali P. Phatnani, Janice C. Jones, and Arno L. Greenleaf \\ Department of Biochemistry, Duke University Medical Center, Durham, North Carolina 27710
}

\begin{abstract}
CTD kinase I (CTDK-I) of Saccharomyces cerevisiae is required for normal phosphorylation of the C-terminal repeat domain (CTD) on elongating RNA polymerase II. To elucidate cellular roles played by this kinase and the hyperphosphorylated CTD (phosphoCTD) it generates, we systematically searched yeast extracts for proteins that bound to the phosphoCTD made by CTDK-I in vitro. Initially, using a combination of far-western blotting and phosphoCTD affinity chromatography, we discovered a set of novel phosphoCTD-associating proteins (PCAPs) implicated in a variety of nuclear functions. We identified the phosphoCTD-interacting domains of a number of these PCAPs, and in several test cases (namely, Set2, Ssd1, and Hrr25) adduced evidence that phosphoCTD binding is functionally important in vivo. Employing surface plasmon resonance (BIACORE) analysis, we found that recombinant versions of these and other PCAPs bind preferentially to CTD repeat peptides carrying $\mathrm{SerPO}_{4}$ residues at positions 2 and 5 of each seven amino acid repeat, consistent with the positional specificity of CTDK-I in vitro [Jones, J. C., et al. (2004) J. Biol. Chem. 279, 24957-24964]. Subsequently, we used a synthetic CTD peptide with three doubly phosphorylated repeats $(2,5 \mathrm{P})$ as an affinity matrix, greatly expanding our search for PCAPs. This resulted in identification of approximately 100 PCAPs and associated proteins representing a wide range of functions (e.g., transcription, RNA processing, chromatin structure, DNA metabolism, protein synthesis and turnover, RNA degradation, snRNA modification, and snoRNP biogenesis). The varied nature of these PCAPs and associated proteins points to an unexpectedly diverse set of connections between Pol II elongation and other processes, conceptually expanding the role played by CTD phosphorylation in functional organization of the nucleus.
\end{abstract}

The carboxyl-terminal repeat domain (CTD) ${ }^{1}$ of the largest subunit of eukaryotic RNA polymerase II (Pol II) comprises tandem repeats of the consensus heptapeptide YSPTSPS. This highly conserved sequence, which is repeated 26 times in yeast and 52 times in mammals, is essential for viability. Phosphorylation of the CTD regulates the activities of the polymerase: only Pol II with an unphosphorylated CTD (Pol IIA) is thought to be able to assemble into preinitiation complexes at the promoter, whereas elongating polymerase has a hyperphosphorylated CTD ( $\mathrm{Pol}$ IIO) $(1,2)$. The serines at positions 2 and 5 within the heptad repeat represent major sites of phosphorylation during transcription.

\footnotetext{
${ }^{\dagger}$ Supported by National Institutes of Health Grant GM40505.

(C) 2004 American Chemical Society

*To whom correspondence should be addressed. Phone: 919-684-4030. Fax: 919-684-8885. E-mail: arno@ biochem.duke.edu.

${ }^{1}$ Abbreviations: CTDK-I, CTD kinase I; Pol II, RNA polymerase II; CTD, C-terminal repeat domain; phosphoCTD, hyperphosphorylated CTD; PCTD, phosphoCTD; PCAP, phosphoCTD-associating protein; PCID, phosphoCTD-interacting domain; SGD, Saccharomyces Genome Database; SPR, surface plasmon resonance; RU, response units.
} 
The specific patterns of phosphorylation acquired by the CTD as Pol II traverses a transcription unit are believed to signal the different stages of transcription. The CTD of Pol II at the promoter is predominantly phosphorylated on Ser5, while Ser2 phosphorylation correlates with the presence of Pol II within the coding regions of genes (3). Ser5 phosphorylation has also been found in the coding regions of genes, sometimes at lower levels than at promoters (e.g., refs 4 and 5). These different CTD phosphorylation patterns serve as a guide for the timely recruitment to transcribing Pol II of factors that play a role in transcript biogenesis. For example, Ser5 phosphorylation is important for recruiting capping enzyme early in the transcription cycle $(6,7)$, whereas Ser2 phosphorylation plays a role in recruiting Pcf11, a factor involved in 3'-end formation (8). Modulating the extent and pattern of CTD phosphorylation can thus be an effective way of regulating the CTD's affinity for numerous protein factors, as it can potentially generate a profuse array of different phosphoepitopes (9).

Patterns of CTD phosphorylation are determined by the combined actions of CTD kinases and phosphatases. Two of the four yeast CTD kinases, Srb10 in mediator and Kin28 in TFIIH, have been associated primarily with the process of initiation $(10,11)$. Although both have been shown to assemble into preinitiation complexes (PICs) at the promoter, recent experiments utilizing analogue-sensitive mutants of both kinases suggest different, but partially overlapping roles for both enzymes in promoting transcription (12). The other two CTD kinases, Ctk1 in CTDK-I and Sgv1/Bur1, have been associated primarily with the elongation phase of transcription (13-17). Biochemical studies indicate that CTDK-I can stimulate elongation (17), and in vivo experiments show that elongating Pol II is aberrantly phosphorylated in ctkl mutants $(16,18)$. Also implicating CTDK-I in transcription elongation are genetic interactions with various elongation factors (19-21). Analogous genetic studies coupled with recent biochemical experiments also imply such a role in elongation for Sgv1/Bur1 $(15,20$, 22), although in a recent study Sgv1/Bur1 catalytic mutants appeared to have no effect on cotranscriptional CTD phosphorylation (13). In contrast to the four kinases, there are two known CTD phosphatases in yeast, Fcp1 and Ssu72 (23-26). Biochemical as well as genetic evidence indicates that both proteins may function as CTD phosphatases in the context of transcription $(16,19,20,25-31)$.

It is the interplay between these CTD kinases and phosphatases that influences which factors associate with transcribing polymerase and when during the transcription cycle such associations occur. As mentioned, the recruitment of capping enzyme early in the transcription cycle is believed to be one consequence of CTD phosphorylation on Ser5 by Kin28 $(6,7)$. Consistent with this, capping enzyme and Kin28 interact genetically (6). After the action of Kin28, Ser2 of the CTD is thought to be phosphorylated by CTDK-I: Ctk1 cross-links to genes both at promoters and in coding regions, and in the absence of CTDK-I, Ser2 phosphorylation in coding regions appears to be greatly reduced (16). In support of this idea, we recently demonstrated that CTDK-I most efficiently phosphorylates Ser2 of CTD peptides that are prephosphorylated on Ser5, generating CTD repeats that are doubly phosphorylated on both serines 2 and 5 (32). Just as capping enzyme recruitment attends CTD phosphorylation by Kin28, the recruitment of factors involved in elongation and RNA processing is considered to be one consequence of CTD phosphorylation by CTDK-I (4,33-36). Consistent with this, CTK1, encoding the catalytic subunit of CTDK-I, has been found to interact genetically with several of these factors $(19-21,35)$.

A growing body of evidence also suggests that the role of CTD phosphorylation is not confined to recruiting factors that mediate mRNA maturation. For example, CTD phosphorylation by CTDK-I also plays a role in recruiting the histone H3 Lys36 methyltransferase Set2, and ctk $1 \Delta$ cells are defective for histone H3 Lys36 methylation $(37,38)$. Moreover, five of eight mammalian phosphoCTD-associating proteins (PCAPs) recently identified play roles in DNA 
or chromatin transactions (39). These and other results suggest that the functional repertoires of both the PCTD and its kinases have been greatly underestimated.

With a view to further elucidating the cellular role of CTDK-I, and believing that only a small subset of phosphoCTD-associating proteins had thus far been identified, we undertook a systematic search for yeast proteins that bound the hyperphosphorylated CTD made by CTDKI. We describe the identification of several novel phosphoCTD-associating proteins using a combination of ion-exchange chromatography, phosphoCTD affinity chromatography, and far-western analysis. We detail the further characterization of some of these new proteins. Using surface plasmon resonance (SPR), we show that proteins that bind the CTDK-Igenerated PCTD preferentially bind doubly phosphorylated CTD repeats, consistent with the positional specificity of CTDK-I in vitro. Finally, we describe how we used doubly phosphorylated CTD peptide columns to expand our search for PCAPs. We discuss how the results of this search implicate CTDK-I in a diverse array of cellular processes and unmask connections that shed light on the role of CTD phosphorylation in the organization of nuclear function.

\section{MATERIALS AND METHODS}

\section{Purification of PCAPs. (A) Method 1: HiTrap S Fractionation}

PCAPs were purified from an extant crude yeast extract (the ammonium sulfate pellet from ref 40 resuspended in $25 \mathrm{mM}$ HEPES, pH 7.6, $150 \mathrm{mM} \mathrm{KCl}$, and $0.1 \mathrm{mM}$ EDTA). The crude extract was clarified by centrifugation and diluted in buffer BH (25 mM HEPES, pH 7.6, 8\% glycerol, and $0.1 \mathrm{mM}$ EDTA with $1 \mathrm{mM}$ DTT and $1 \mathrm{mM}$ PMSF) to obtain a conductivity equivalent to that of $0.15 \mathrm{M} \mathrm{KCl}$. This diluted extract formed the onput for a $5 \mathrm{~mL}$ cationexchange HiTrap S column (Amersham). The column was washed with $\mathrm{BH}+0.15 \mathrm{M} \mathrm{KCl}$, and bound proteins were eluted using a linear salt gradient (from 0.15 to $1.0 \mathrm{M} \mathrm{KCl}$ ). Protein fractionation was visualized by Coomassie staining following SDS-PAGE on 4-20\% Tris• $\mathrm{HCl}$ gradient Ready Gels (from Bio-Rad). Replicates of the stained gels were transferred to Hybond $\mathrm{C}$ extra reinforced nitrocellulose membrane (Amersham) and probed with radiolabeled recombinant $\beta$-gal-CTD fusion protein exhaustively phosphorylated in vitro by CTDK-I as described previously $(36,41)$. Bound probe was detected by autoradiography.

PCAP-containing fractions from the HiTrap S column were further applied to a phosphoCTD column made by cross-linking GST-phosphoCTD (phosphorylated as above) to agarose beads [AminoLink Plus (Pierce)]. After being loaded at $0.15 \mathrm{M} \mathrm{KCl}$, the $100 \mu \mathrm{L}$ column was washed, and bound proteins were eluted using steps of increasing salt $(0.5,1.0,1.5$, and $2.0 \mathrm{M})$; four $50 \mu \mathrm{L}$ aliquots were collected at each salt step. Ten percent of each elution, along with the onput (OP), flow-through (FT), and wash samples, was subjected to SDS-PAGE and stained with silver. Ten microliters of the second $0.5 \mathrm{M}$ fraction, along with the OP (onput), FT (flowthrough), and W (wash), was separated by SDS-PAGE, transferred to nitrocellulose, and probed with recombinant GST-phosphoCTD in a far-western assay. Stained bands corresponding to bands in the far-western assay were excised from the gel, frozen, and sent to the W. M. Keck Foundation Biotechnology Resource Laboratory at Yale University or the Duke University Proteomics Center for in-gel trypsinization and MALDI-MS analysis.

\section{(B) Method 2: CM Fractionation}

Frozen yeast cells ( $330 \mathrm{~g}$ ) were disrupted in liquid nitrogen as described previously (40) and resuspended in buffer B [25 mM Tris• $\mathrm{HCl}, \mathrm{pH}$ 7.4, 0.2 M KCl, 1 mM EDTA, $1 \mathrm{mM}$ DTT, $\operatorname{PMSF}$ (1:1000 dilution of a saturated solution in 2-propanol), and $0.05 \mu \mathrm{g} / \mathrm{mL}$ leupeptin]. The resulting crude extract was centrifuged at $10000 \mathrm{~g}$ (8000 rpm in a Sorvall GS-3 rotor) for $1 \mathrm{~h}$ at $4{ }^{\circ} \mathrm{C}$ to remove cell debris. Ammonium sulfate $\left[\left(\mathrm{NH}_{4}\right)_{2} \mathrm{SO}_{4}\right]$ was gradually added to the 
supernatant to a final concentration of $50 \%(\sim 313 \mathrm{~g} / \mathrm{L})$, with constant stirring at $4{ }^{\circ} \mathrm{C}$. Precipitated material was recovered by centrifugation at $25000 \mathrm{~g}$ (13000 rpm in a Sorvall SLA-1500 rotor) for $45 \mathrm{~min}$ at $4{ }^{\circ} \mathrm{C}$. The resulting pellet was resuspended in buffer $\mathrm{BH}$ such that the conductivity was equivalent to that of $0.2 \mathrm{M}\left(\mathrm{NH}_{4}\right)_{2} \mathrm{SO}_{4}$. This material was then passed through a DEAE column (200 mL, Macro-Prep DEAE support, Bio-Rad) which had been preequilibrated in buffer $\mathrm{BH}+0.2 \mathrm{M}\left(\mathrm{NH}_{4}\right)_{2} \mathrm{SO}_{4}$. The flow-through (FT) from the DEAE column was diluted in buffer $\mathrm{BH}$ such that the conductivity was equivalent to that of $0.15 \mathrm{M}$ $\mathrm{KCl}$ and stirred with $100 \mathrm{~mL}$ of Macro-Prep CM resin (Bio-Rad) which had been preequilibrated in buffer $\mathrm{BH}+0.15 \mathrm{M} \mathrm{KCl}$. After 80 min at $4{ }^{\circ} \mathrm{C}$, the resin was transferred to a column for washing and elution. After being washed with $300 \mathrm{~mL}$ ( 3 column volumes) of buffer $\mathrm{BH}+0.15 \mathrm{M} \mathrm{KCl}$, the column was developed with a gradient of $0.15-1.0 \mathrm{M} \mathrm{KCl}$ over $300 \mathrm{~mL}$ (the gradient was held at $1.0 \mathrm{M} \mathrm{KCl}$ over a further $50 \mathrm{~mL}$ ). Fourteen-milliliter fractions were collected and analyzed for PCAPs by staining and far-western blotting (as described above). PCAPs from CM fractions were purified essentially as described for HiTrap $\mathrm{S}$ fractions: when required, elutions from the GST-PCTD column were concentrated using Strataclean resin (Stratagene) according to the manufacturer's protocol. CM fraction 16 was applied to both a GST-PCTD column and a biotinylated CTD-peptide column (three-repeat CTD peptide doubly phosphorylated on serines 2 and 5 of each heptad repeat) attached to streptavidin-agarose beads (Ultralink, Pierce) following the manufacturer's protocol.

\section{(C) Method 3: P11 Fractionation}

Frozen yeast cells ( $750 \mathrm{~g}$ ) were disrupted in liquid nitrogen as described previously (40) and resuspended in buffer BY-AS(400) [25 mM HEPES, pH 7.6, 0.4 M ( $\left.\mathrm{NH}_{4}\right)_{2} \mathrm{SO}_{4}, 1$ mM EDTA, $1 \mathrm{mM}$ DTT, PMSF (1:1000 dilution of a saturated solution in 2-propanol), and protease inhibitor cocktail for fungal extracts (Sigma)]. This ionic strength [0.4 M $\left.\left(\mathrm{NH}_{4}\right)_{2} \mathrm{SO}_{4}\right]$ has been shown to be sufficient to extract factors associated with elongating Pol II from yeast $(42,43)$, and we have found that it is also more than sufficient to disengage virtually all mammalian PCAPs from RNA Pol II in a chromatin pellet from HeLa cells (39). The crude extract was centrifuged at $14000 \mathrm{~g}$ ( $8000 \mathrm{rpm}$ in a Sorvall SLC-6000 rotor) for $45 \mathrm{~min}$ at $4{ }^{\circ} \mathrm{C}$ to remove cell debris. The $\mathrm{pH}$ of the supernatant was then adjusted to 7 with the addition of $1.0 \mathrm{M} \mathrm{NaOH}$, and NP-40 was added to a final concentration of $1 \%$. Ammonium sulfate was then gradually added to the supernatant to a final concentration of $50 \%(\sim 313 \mathrm{~g} / \mathrm{L})$, with constant stirring for $45 \mathrm{~min}$ at $4{ }^{\circ} \mathrm{C}$. Precipitated material was recovered by centrifugation at $30000 \mathrm{~g}(14000 \mathrm{rpm}$ in a Sorvall SLA- 1500 rotor) for $45 \mathrm{~min}$ at $4{ }^{\circ} \mathrm{C}$. The resulting pellet was resuspended in buffer $\mathrm{BH}$ such that the conductivity was equivalent to that of $0.15 \mathrm{M} \mathrm{KCl}$. This material was then passed through a DEAE column $(100 \mathrm{~mL})$ which had been preequilibrated in buffer $\mathrm{BH}+0.15$ $\mathrm{M} \mathrm{NaCl}$. Proteins that might have bound the DEAE column were eluted with a step of $0.35 \mathrm{M}$ $\mathrm{NaCl}$. No PCAPs were found to be retained on the DEAE column when assayed by far-western blotting. Half the flow-through (FT) from the DEAE column was fractionated on a P11 column (cellulose phosphate fibrous cation exchanger, Whatman) also preequilibrated in buffer $\mathrm{BH}+$ $0.15 \mathrm{M} \mathrm{NaCl}$. Specifically, the DEAE FT $(550 \mathrm{~mL})$ was centrifuged at $38700 \mathrm{~g}(18000 \mathrm{rpm}$ in a Sorvall SS-34 rotor) for $25 \mathrm{~min}$ at $4{ }^{\circ} \mathrm{C}$ and incubated with $125 \mathrm{~mL}$ of P11 resin overnight at $4{ }^{\circ} \mathrm{C}$ with gentle rocking. The material was then poured into a column (internal diameter approximately $2.5 \mathrm{~cm}$ ) and washed with buffer $\mathrm{BH}+0.15 \mathrm{M} \mathrm{NaCl}$ at $2.5 \mathrm{~mL} / \mathrm{min}$ until UV absorbance returned to baseline (this and subsequent steps at $4{ }^{\circ} \mathrm{C}$ ). The column was developed with a two-step linear gradient, first from 0.15 to $1.0 \mathrm{M} \mathrm{NaCl}$ over 4 column volumes and then at $1.0 \mathrm{M} \mathrm{NaCl}$ for 1 column volume, and $10 \mathrm{~mL}$ fractions were collected.

Fractions were analyzed for PCAPs by far-western blotting. On the basis of PCAP distribution, P11 fractions from the early, middle, and late parts of the salt gradient were pooled (fractions 21-25, 29-31, and 38-41, respectively) and subjected to affinity column purification steps. Affinity columns were made by immobilizing three-repeat biotinylated CTD peptides (Figure 
5A) to $300 \mu \mathrm{L}$ of a tetrameric avidin resin (Tetralink, Promega) following the manufacturer's protocol. The molar concentration of peptide coupled to the matrix was determined by monitoring the $A_{280}$ of the peptide solution before and after coupling. After being passed through a control column (tetrameric avidin resin with no peptide), pooled P11 fractions were loaded onto the peptide columns in buffer $\mathrm{BH}+0.1 \mathrm{M} \mathrm{NaCl}$, and the columns were washed with $4.0 \mathrm{~mL}$ ( 13 column volumes) of the same buffer. Both the control and experimental columns were developed in parallel. Bound proteins were eluted with steps of $0.3,0.5$, and 1.0 $\mathrm{M} \mathrm{NaCl}$; four $150 \mu \mathrm{L}$ aliquots were collected at each salt step. Twenty-four microliters of each aliquot was subjected to SDS-PAGE (on 4-20\% Tris $\bullet \mathrm{HCl}$ gradient gels from Bio-Rad) and either stained with Coomassie or transferred to nitrocellulose and probed with GST-PCTD as before. Stained bands were excised from the gels and submitted to the Duke University Proteomics Center for in-gel trypsinization and mass spectrometry.

\section{Characterization of PCAPs. (A) Purification of Recombinant Fusion Proteins}

PCR products corresponding to the desired regions of the proteins were amplified from yeast genomic DNA. A BamHI site was inserted into the forward primer and a Sal I site into the reverse primer. The PCR products were purified, digested with BamHI and Sal I, and ligated into pMAL-c2G (NEB). MBP fusion proteins were purified from bacteria according to the manufacturer's protocol.

\section{(B) Far-Western Assays}

The probe for far-western assays was generated by exhaustively phosphorylating either a $\beta$ gal- or GST- (yeast) CTD fusion protein with CTDK-I in vitro as described previously (41).

Samples to be probed were run on precast $4-20 \%$ Tris $\bullet \mathrm{HCl}$ gradient gels (from Bio-Rad), electrophoretically transferred to nitrocellulose membrane, and incubated overnight in blocking buffer (PBS with $0.2 \%$ Tween-20 and 3\% nonfat dry milk) with $1 \mathrm{mM}$ PMSF and 2 mM DTT with rocking (this and subsequent steps at $4{ }^{\circ} \mathrm{C}$ ). The blot was then probed with (radiolabeled) phosphoCTD fusion protein for $2 \mathrm{~h}$ and washed $4 \times 7 \mathrm{~min}$ in PBS with $0.2 \%$ Tween-20. The probe was then detected in one of two ways: (1) the blot was air-dried and exposed to film or (2) the GST-phosphoCTD probe where mentioned was detected using an affinity-purified anti-GST antibody according to standard protocols.

When necessary, blots were stripped as follows: incubation, with frequent agitation, in stripping buffer (100 $\mathrm{mM} \beta$-mercaptoethanol, $2 \%$ SDS, and $62.5 \mathrm{mM}$ Tris $\bullet \mathrm{HCl}, \mathrm{pH}$ 6.7) for $50 \mathrm{~min}$ at $50^{\circ} \mathrm{C}$; washing $4 \times 10 \mathrm{~min}$ in blocking buffer at room temperature; incubation in blocking buffer for $40 \mathrm{~min}$ at room temperature. The stripped blots were then reprobed as indicated in the figure legends.

\section{(C) Surface Plasmon Resonance (BIACORE) Analysis}

Biotinylated three-repeat CTD peptides (Figure 5A) were diluted to $0.1 \mathrm{mg} / \mathrm{mL}$ in phosphatebuffered saline and passed over a streptavidin (SA) sensor chip such that the surface of the chip was saturated with peptide. Two chips were made: the first had the non-phospho-, 5phospho-, and 2,5-phosphopeptides, as well as an empty flow cell; the second had the 2phospho-, 5-phospho-, and 2,5-phosphopeptides as well as a scrambled peptide with six phosphoserines (Figure 5A). To ensure that each surface was active and specific, the prepared surfaces were tested with the CTD phosphorylation-specific monoclonal antibodies 8WG16, H5, and H14 (Covance). The N-terminal 300 amino acids encompassing the SET domain of Set2 fused to MBP [MBP-Set2(1-300)] served as a good negative control, displaying no detectable binding specific to any of the peptides tested. Various recombinant PCAPs were diluted to $2 \mu \mathrm{M}$ (MBP fusion proteins were diluted in $20 \mathrm{mM}$ Tris $\bullet \mathrm{HCl}, \mathrm{pH} 7.4,0.2 \mathrm{M} \mathrm{NaCl}$, $1 \mathrm{mM}$ EDTA, and $10 \mathrm{mM}$ maltose, while the Ess1 and Prp40 constructs were diluted in 
phosphate-buffered saline) and interacted with the peptides on the chip(s) for $110 \mathrm{~s}$ at $30 \mu \mathrm{L} /$ min. The dissociation time was $300 \mathrm{~s}$, followed by surface regeneration with $1.0 \mathrm{M} \mathrm{MgCl}_{2}$ $(100 \mu \mathrm{L}$ at $50 \mu \mathrm{L} / \mathrm{min})$.

\section{(D) Splicing Assays}

Cells growing in $100 \mathrm{~mL}$ of YPD medium were harvested at an $A_{600}=1.0$, incubated overnight in starvation medium, harvested, and returned to prewarmed YPD medium at $30^{\circ} \mathrm{C}$. Aliquots were removed at various intervals after refeeding. An aliquot removed before returning the cells to YPD served as the "0" time point. Total RNA was extracted by a hot phenol method (44). Twenty micrograms of total RNA was hybridized overnight at $67^{\circ} \mathrm{C}$ to the radiolabeled ANTIRP51A2 probe (5' GCACGCT-

TGACGGTCTTGGTTCTAACTCTACCCTATTAAAAT-

GACGAAAAGCAATACAAAATAAAAAGTCCTCGG 3'). Nuclease protection assays were performed using mung bean nuclease (from NEB) as described by Iyer and Struhl (45).

\section{RESULTS}

\section{Isolation of Yeast PhosphoCTD-Associating Proteins (PCAPs)}

In an effort to understand the consequences of CTD phosphorylation by CTDK-I, we undertook to identify proteins that specifically interact with the CTDK-I-phosphorylated form of the CTD (PCTD). Our approach used a combination of ion-exchange chromatography, affinity chromatography, and far-western blotting to identify such PCTDassociating proteins (PCAPs). CTDK-I was used to exhaustively phosphorylate a GST-CTD fusion protein in vitro [as assayed by a mobility shift on SDS-PAGE (e.g., ref 41)], and this hyperphosphorylated PCTD fusion protein was used to make the matrix for affinity purification as well as the probe for far-western analysis. The general purification scheme for PCAPs is outlined in Figure 1.

\section{(A) Methods 1 and 2}

An extant yeast extract (40) was first fractionated on a cation-exchange HiTrap S column (method 1). Bound proteins were eluted with increasing salt, subjected to SDS-PAGE, and visualized by Coomassie staining (Figure 2A). To identify potential PCAPs, replicates of the stained gels were transferred to nitrocellulose and probed in a far-western assay using radiolabeled recombinant $\beta$-gal-PCTD. As seen in Figure $2 \mathrm{~B}$, this approach reveals a variety of PCAPs eluting from the column. For example, fractions 23, 25, and 27 have several bands that are detected by the PCTD probe. The pattern of possible phosphoCTD-interacting proteins does not mirror the profile of proteins eluted from the ion-exchange column (not all lanes have putative PCAPs, and not all proteins in any given lane interact with the probe), arguing against the simple possibility that the PCTD probe acts merely as a polyanion (see also discussion in ref 39 and Figure 5G-J).

Since there were many other proteins in the fractions that contain putative PCAPs and it was not possible to correlate a band in the far-western assay with a given Coomassiestained band, HiTrap S fractions were subjected to GST-PCTD affinity chromatography to better enrich for PCAPs. The staining profile of the elutions in Figure 2C, which illustrates one such purification of PCAPs from HiTrap $S$ fraction 23, shows that proteins were indeed fractionated on the basis of PCTD association. Most PCAPs were retained on the column (Figure 2D, compare onput and flow-through), and these constitute only a small fraction of the total proteins in the onput (Figure 2C, compare onput and flow-through). All of these proteins were recovered in a few well-defined fractions (Figure 2C, lanes corresponding to $0.5 \mathrm{M}$ elution). To determine which of these proteins associates with the phosphoCTD by binding directly to it, we performed a far-western assay using hyperphosphorylated GST-PCTD as probe (Figure 2D). The bands in the far-western assay correspond to five distinct bands in the stained gel. These stained bands 
were excised from the gel and identified by mass spectrometry as Ssd1, Hrk1, Ssd1, Set2, Rgd1, and Hrr25. Again, note that several proteins seen by staining do not bind the PCTD in the far-western analysis (Figure 2D). The binding of Ssd1, Hrr25, and Set2 to the PCTD was further characterized as described below.

Fractions 19-22, $24+25,26-28,29-33$, and 34-38 from the HiTrap S column were also subjected to a similar analysis. As it was not possible in all cases to equate a stained band with a far-western band, all major stained bands were excised from the gel and analyzed by mass spectrometry. Hrk1, Rgd1, and Hrr25 were identified again (data not shown). In most cases, however, the sample was insufficient for unambiguous identification.

In an effort to improve the yield of PCAPs, the above general approach was applied to a new, different extract, and a different ion-exchange column was used for the initial chromatography step (method 2). These modifications did not dramatically change the overall protein pattern and PCAP profile for the ion-exchange column (not shown). We then passed the ion-exchange column fractions through a control (GST) column before applying them to a GST-PCTD matrix. Bound proteins from both columns were eluted with salt steps as before, concentrated (see Materials and Methods), subjected to SDS-PAGE, and stained with Coomassie (one example is shown in Figure 3). All stained bands (marked with asterisks) were excised from the gel and identified by mass spectrometry. As indicated in Figure 3, several proteins were identified by method 2 that had also previously been identified by method 1 (Hrk1, Set2, and Hrr25). Method 2 also led to the purification of Ess1 [which had previously been shown to bind the PCTD (36)]. The similarity of results obtained by both methods 1 and 2 attests to the validity of the overall approach as a general PCAP purification strategy.

However, results in Figure 2B (and data not shown) indicate that a number of potential PCAPs remain unidentified, implying that further refinements to the purification strategy would be required to optimize recovery and identification of PCAPs. We reasoned that we could refine our purification scheme if we understood in more detail the PCTD binding properties of individual PCAPs. Toward this end, we characterized recombinant versions of five distinctly different PCAPs [Ssd1, Set2, Hrr25, Ess1, and the previously identified PCTD-interacting splicing factor Prp40 (34)] in terms of their phosphoCTD-interacting domains (PCIDs) and/ or their phosphoepitope binding specificities, as described in the following sections.

\section{Characterization of PCAPs. (A) Identification of the PCTD-Interacting Domain in Ssd1}

Ssd1, a member of the ribonuclease II family of proteins (Figure 4A), has been implicated in diverse pathways regulating cell growth and differentiation (e.g., refs 46-56). It has been shown to interact genetically with many different proteins, but very little is known about its biochemistry. Despite its being in the RNase II family, no RNase activity has been demonstrated for Ssd1; however, it can bind RNA and is thought to be RNA-associated in vivo (49). SSD1 is polymorphic, and four different alleles having been identified in laboratory strains: SSD1-v1, SSD1-v2, ssd1-d1, and $s s d 1-d 2$. The d alleles are recessive to the $\mathrm{v}$ alleles and encode a C-terminal truncation of the protein $(46,53)$. The presence of the $d$ allele affects the penetrance of mutations in many different genes, and in fact, we had previously found that a deletion of CTKI (the catalytic subunit of CTDK-I) was synthetically lethal at $37^{\circ} \mathrm{C}$ in the presence of the $s s d 1-d$ allele (J. M. Lee and A. L. Greenleaf, unpublished data).

With a view to determining the PCTD binding region of Ssd1, we probed various recombinant MBP-Ssd1 fusion proteins in a far-western assay. Figure 4B confirms that Ssd1 is a PCAP and demonstrates that the $p$ hosphoCTD-interacting domain (PCID) lies within the first 240 amino acids of the protein (Figure 4B, lane 2). Although this is a region with no obvious homology to known PCIDs, it is essential for the function of Ssd1 in vivo $(47,57)$. Deletions from either end of this 240 residue-fragment appear to decrease the strength of PCTD binding 
(Figure 4B, lanes 3-5). Although complete characterization of this domain awaits future experiments, we have determined that binding of the $\mathrm{N}$-terminal domain to $\mathrm{CTD}$ repeats depends on their pattern of phosphorylation (Figure 5C,G; see below).

(B) PCTD Binding Domains in Set2

The SET domain-containing protein Set2 (Figure 4A) has recently been shown by several groups to interact with the phosphorylated form of RNA polymerase II both in vitro and in vivo $(37,38,58-64)$. Set2 is a histone methyltransferase that methylates lysine 36 of histone $\mathrm{H} 3$; its catalytic activity resides in its SET domain. In addition to the SET domain, Set2 also has a WW domain and a predicted coiled-coil domain (SMART domain database, http://smart.embl-heidelberg.de/). To identify the domain in Set2 that mediates PCTD binding, we employed the far-western assay as before to screen various recombinant MBP-Set2 fusion proteins. This approach mapped the PCTD binding activity to a location C-terminal to the SET domain (Figure 4B, lane 7, and data not shown). Dissecting the non-SET domain part of the protein led to finding a region at the extreme carboxyl-terminal end of Set2 (amino acids 619733) that binds directly to the PCTD in vitro [this region, termed the SRI (65), is not homologous to any previously described PCID]. Correspondingly, a deletion of this region abolishes the ability of Set2 to immunoprecipitate Pol IIO, and it eliminates methylation uniquely of lysine 36 of histone $\mathrm{H} 3$ (65). These data support a functional role for the C-terminal 115 amino acids in PCTD binding in vivo.

However, in the process of dissecting Set2 to find its PCTD-interacting domain (PCID), we observed that an MBP-Set2(1-618) construct lacking the SRI region is also able to interact directly with the PCTD when probed in a far-western assay, albeit weakly (data not shown). Since this region of Set 2 contained a WW domain, and because certain WW domains bind directly to the PCTD $(34,36)$, we wished to establish whether it was the WW domain-containing region of Set2 that mediates interaction of this region of Set 2 with the PCTD. To this end, a recombinant MBP fusion protein carrying the WW domain of Set 2 flanked by 50 amino acids on either side [MBP-Set2(425-551)] was used as a probe in a "reverse" far-western assay. GST-CTD and GST-PCTD fusion proteins were blotted to nitrocellulose and probed with MBP-Set2(425-551), which was then detected with an anti-MBP antibody. As shown in Figure $4 \mathrm{C}$, this region of Set2 (containing the WW domain) does indeed bind directly to the PCTD; moreover, it requires the CTD to be phosphorylated in order to bind. In contrast, purified recombinant MBP alone does not bind either the GST-CTD or GST-PCTD (Figure 4D). Western blotting using an anti-GST antibody on the same blot as in Figure 4C demonstrates the presence of the GST-CTD fusion proteins in both lanes (Figure 4E). Although there are several slower mobility bands in the PCTD lane [corresponding to intermediates of the phosphorylation reaction (cf., e.g., ref 41)], the MBP-Set2-(425-551) fusion protein selectively binds to the slowest migrating (most highly phosphorylated) form of the PCTD (compare panels $\mathrm{C}$ and $\mathrm{E}$ of Figure 4). Set2 thus appears to have at least two regions which can bind directly to the PCTD. An appreciation of their functional significance can only attend detailed future comparisons of these two PCIDs in Set2.

\section{(C) Further Characterization of Hrr25: Confirmation of the Interaction and Specificity for the Phosphorylated Form of the CTD}

Hrr25, a casein kinase I isoform, physically interacts with and phosphorylates Swi6 and is involved in mediating the transcriptional response to DNA damage caused by methyl methanesulfonate (MMS) or treatment with hydroxyurea (HU); specifically, hrr25 $\Delta$ cells were shown to be defective in the transcriptional induction of $R N R$ gene expression upon exposure to HU (66). Recombinant MBP- Hrr25 was used in a (reverse) far-western assay to confirm its in vitro interaction with the phosphoCTD. Figure $4 \mathrm{~F}$ shows that Hrr25 binds directly to the PCTD and that this binding requires the CTD to be phosphorylated. As for the Set2 WW 
domain-containing construct, it can be seen that the MBP-Hrr25 fusion protein binds to only the slowest migrating form of the PCTD (compare panels E and F of Figure 4).

\section{(D) SPR (BIACORE) Analysis: Specificity of PCAPs for Doubly Phosphorylated CTD Repeats}

We recently demonstrated that CTDK-I can efficiently generate doubly phosphorylated CTD repeats in vitro (32). We were hence intrigued by the results in Figure 4, where it appeared that the WW domain of Set2, as well as full-length Hrr25, bound selectively and specifically to the most highly phosphorylated form of the PCTD generated by CTDK-I. Therefore, with the objective of further characterizing the phosphoCTD-epitope binding specificity of these and other PCAPs, we used surface plasmon resonance (SPR) measurements (BIA-CORE) to examine the binding of a subset of PCAPs to a set of chemically synthesized CTD peptides with phosphorylated serines in exactly known positions (Figure 5A), which presumably mimic phosphoCTD forms likely encountered by these proteins in vivo.

Purified recombinant proteins, carrying known or presumed PCIDs of different PCAPs, were interacted with biotinylated CTD peptides immobilized on the surface of a streptavidin sensor chip (Figure 5B-F). Binding of the PCAPs to the peptides was recorded in BIACORE sensorgrams, where binding is represented by response units (RU, on the $y$-axis) as a function of time (on the $x$-axis). The sensorgrams in Figure 5B-F reveal several interesting facts. First, all proteins tested exhibit virtually no binding to the non-phosphoCTD peptide under these conditions, corroborating the serine phosphate dependence of the binding observed in farwestern analysis. Second, Figure 5B confirms that the WW domain-containing construct of Set2 can indeed bind directly to the PCTD. There are thus at least two independent phosphoCTD binding domains in Set2, one encompassed by amino acids 425-551 and the other by amino acids 619-733 (the SRI region; see ref 65). Third, Figure 5C shows that the $\mathrm{N}$-terminal 160 amino acids in Ssd1 are sufficient for phosphoCTD binding. In light of the farwestern analysis in Figure 4B, it will be interesting to see whether the various fragments of the Ssd1 PCID differ at all in their specificity and whether this domain can be dissected further. Fourth, Figure 5D, in addition to confirming the interaction between the C-terminal FF domains of splicing factor Prp40 and the phosphoCTD (amino acids 267-583; see ref 34), shows that this region of the protein can also associate specifically with the 5P peptide. Fifth, a comparison of the binding sensorgrams of the interaction between various PCAPs and the 2,5P peptide (Figure 5B-F) illustrates that these proteins vary widely in terms of their binding kinetics. The WW domain of Ess 1, for example, displays very fast association and dissociation rates (Figure $5 \mathrm{~F}$ ); in contrast, Hrr 25 has both a slower association as well as a slower dissociation rate (Figure 5E). Finally, the binding sensorgrams in Figure 5B-F also demonstrate that all PCAPs tested bind with the highest RU level to the 2,5P peptide, consistent with the positional specificity of CTDK-I in vitro (32).

The binding of PCAPs to the three-repeat 2,5P peptide, which contains six phosphoserine residues, is presumably influenced both by the number of negatively charged phosphate groups and by their sequence context. To assess how much of the binding to the 2,5P peptide might be due to its six phosphoserines alone, purified recombinant PCAPs were tested against a scrambled CTD-like peptide (6PC, shown in Figure 5A), which also carried six phosphoserines but not in the context of the CTD repeat sequence. PCAPs were interacted with this peptide and with three CTD consensus repeat 21-mers with either six phosphoserines $(2,5 \mathrm{P})$ or three phosphoserines ( $2 \mathrm{P}$ and $5 \mathrm{P}$ ), as shown in Figure 5A, immobilized on a second streptavidin sensor chip. As the results of Figure 5G-J indicate, even after subtracting the binding to 6PC, all proteins tested show the highest RU level on the 2,5P peptide. Interestingly, the PCID of Ssd1 as well as the FF domains of Prp40 appears to bind either one or both of the $2 \mathrm{P}$ and $5 \mathrm{P}$ peptides more strongly than the $6 \mathrm{PC}$ peptide (Figure 5G,H). Thus, although the six phosphoserines on the 2,5P peptide make a contribution to PCAP binding, they clearly do not 
account for all of the binding to this peptide; the phosphoserines in the context of the CTD heptad sequence are critical determinants of binding specificity.

\section{Optimizing Methods for PCAP Purification and Identification. (A) Affinity Columns Utilizing Synthetic Phosphopeptides}

In light of the data in Figure 5, as well as our recently published results (32), we asked whether a three-repeat CTD peptide phosphorylated at serines 2 and 5 of each heptad repeat could substitute for a CTDK-I-generated PCTD as an affinity matrix for the purification of PCAPs. Such a replacement would not only conserve CTDK-I [preparing each PCTD column required expenditure of a relatively large amount of CTDK-I, which is purified in only low amounts from yeast extract (41)] but would also allow preparing columns with higher densities of binding determinants. Thus we coupled the biotinylated 2,5P peptide used in the BIACORE analysis (shown in Figure 5A) to streptavidin- agarose beads and used this material in a test purification of PCAPs from a fraction eluted from the CM column (Materials and Methods). Results showed (Figure 6) that the far-western profile of the 2,5P column recapitulates that of the PCTD column; one slight difference is that PCAPs are eluted from the peptide column at lower salt than from the PCTD column. Studies described below indicate that yields are improved by coupling more peptide to the affinity matrix. Also, we found that a different column matrix significantly reduced nonspecific binding of contaminant proteins (below and data not shown). Thus, a doubly phosphorylated $2,5 \mathrm{P}$ peptide column can indeed serve as a convenient substitute for the CTDK-I-generated PCTD column.

\section{(B) Method 3: Combining New Extraction Procedures with Different Column Materials}

In further efforts to improve efficiency and increase the yield of PCAPs, we also modified the initial extraction protocol and changed the ionexchange column fractionation (Materials and Methods). Ionexchange column (P11) fractions were stained and probed as before and are shown in Figure 7. Comparing the far-western pattern of the onput and flow-through of the P11 column (Figure 7B, lanes 1 and 2) shows that PCAPs were indeed retained on the P11 column, and a comparison of the far-western profiles of the elutions from the P11 column (Figure 7B) with the elutions from the HiTrap S column (Figure 2B) shows that PCAPs are better enriched on the P11 column. Note that proteins that might have bound to the DEAE column were eluted with a step of $0.35 \mathrm{M} \mathrm{NaCl}$ and were probed in a far-western assay (Figure 7B, lane 3). No PCAPs were seen to be retained on the DEAE column by this assay. The PCAP profile of the P11 column differs greatly from the overall protein profile; that is, only a minority of proteins that bind the P11 cellulose phosphate resin (stained gel) also bind the PCTD in the far-western assay. Furthermore, strong PCAP bands (far-western) mostly do not correspond to strong stained bands.

\section{(C) Further Purification of PCAPs from the P11 Column}

On the basis of the distribution of PCAPs (as determined by the far-western assay), sets of P11 fractions (representing early, middle, and late parts of the salt gradient elution) were pooled, and PCAPs therein were further purified by affinity chromatography using a biotinylated 2,5P peptide (see Materials and Methods).

To determine the optimal amount of peptide to immobilize to the avidin matrix, P11 middle fractions were applied to columns containing different amounts of 2,5P peptide, and the columns were developed as described in Materials and Methods (Figure 7D). First, it can be seen that the control column (lanes C) bound no PCAPs (far-western blot) and no detectable protein (stained gel), in contrast to the different matrix material used earlier (cf. Figure 3 and data not shown). Second, by comparison of lanes P1 and P2 (which represent elutions from two different peptide columns with approximately 25 and $50 \mu \mathrm{M} 2,5 \mathrm{P}$ peptide, respectively) to each other and to lane $\mathrm{C}$ (which represents the elution from the control column), it is apparent 
not only that proteins (PCAPs) are selectively enriched on the experimental columns but that this enrichment is dependent on the amount of peptide immobilized on the matrix. All further purifications with a 2,5P peptide column were therefore carried out at a peptide concentration of $50 \mu \mathrm{M}$ (as defined by moles of peptide per volume of beads; see Materials and Methods) on the matrix.

\section{(D) PCAPs Are Enriched on the 2,5P Peptide Column}

We next wished to determine whether the enrichment of proteins on the experimental columns was dependent on the pattern of phosphorylation of the CTD peptide coupled to the matrix. To this end, we prepared additional affinity columns comprising biotinylated three-repeat CTD peptides phosphorylated at either serine 2 of each repeat (2P) or serine 5 of each repeat (5P) (Figure 5A). Both 2P and 5P matrices had a peptide concentration of $75 \mu \mathrm{M}$. Pooled P11 early fractions were passed through a control avidin column and divided into three aliquots; each aliquot was then subjected to affinity chromatography on a different CTD peptide matrix. The three columns were eluted with salt steps as described (Materials and Methods). An examination of the 2P, 5P, and 2,5P lanes in Figure 7C (which represent elutions from the 2P, $5 \mathrm{P}$, and 2,5P columns, respectively) reveals that the selective enrichment of PCAPs on the experimental column is highly dependent on the phosphorylation pattern of the peptide coupled to the matrix; in this case, virtually all of the proteins that bind to a peptide affinity column bind to the $2,5 \mathrm{P}$ matrix but not to the $2 \mathrm{P}$ or $5 \mathrm{P}$ matrices.

Late fractions from the P11 column were also pooled and, after preclearing through a control column, subjected to affinity chromatography using a 2,5P peptide column. The stained gel (Figure 7E) reveals that, once again, proteins are greatly enriched on the 2,5P peptide column as compared to the control column (compare lanes $\mathrm{C}$ and $\mathrm{P}$, which represent elutions from the control and peptide columns, respectively). In addition, far-western blotting demonstrates that the 2,5P peptide column dramatically enriches for PCAPs (Figure 7F). It is worth noting that although a few faint bands are evident in the control lanes by Coomassie staining, these bands do not bind to the PCTD in the far-western assay (compare lanes $\mathrm{C}$ in panels $\mathrm{E}$ and $\mathrm{F}$ of Figure 7). Moreover, bands that do bind the PCTD in the far-western assay are sometimes too faint to be visualized by Coomassie staining (compare lanes $P$ in panels $E$ and $F$ of Figure 7).

Taken together, our results show that PCAPs (proteins that bind the CTDK-I-phosphorylated CTD) are greatly enriched on the 2,5P peptide column. We therefore excised each of the Coomassie-stained bands from the gels shown in Figure 7C-E and identified them by mass spectrometry; Figure 8 lists all of the approximately 100 proteins that were so identified, grouped into functional categories based on extant information. Note that Ssd1, Hrr25, Set2, and Ess1 all bound to the 2,5P column, consistent with their preference for the doubly phosphorylated peptide in the BIACORE analysis.

\section{Functional Implications for CTD Phosphorylation by CTDK-I}

In addition to expected functions, such as transcription elongation and RNA processing, many of the proteins we identified have been previously assigned other functions, including roles in the processes of DNA metabolism, establishment and maintenance of chromatin structure, regulation of intracellular transport, RNA degradation, sn-RNA modification, and snoRNP biogenesis. In view of the above, we hypothesize that these processes are connected to CTD phosphorylation by CTDK-I. Recent results lend credence to this hypothesis. For example, as mentioned earlier, deletion of either CTDK-I catalytic activity or the SRI region of Set2 leads to a specific loss of H3 K36 methylation, suggesting that binding of Set 2 to the PCTD made by CTDK-I is central to its activity in vivo $(37,38,65)$. Analogously, the identification of Hrr25 as a PCAP suggests a role for CTDK-I in modulating DNA damage responses. Indeed, like $h r r 25 \Delta$ cells, $c t k l \Delta$ cells are unable to efficiently induce $R N R$ gene transcription upon exposure 
to DNA damaging agents (67). Do the splicing factors found in the current or previous work to be PCTD-associated (Prp40, Snu56, Ssd1) therefore entail a role for CTDK-I in splicing?

\section{(A) ctk1 $\Delta$ Cells Are Defective in Splicing}

To test whether $c t k l \Delta$ cells were defective in splicing, we assayed the splicing of the endogenous RPS17A transcript [which codes for a ribosomal protein (RP)] at various intervals after returning starved $c t k 1 \Delta$ cells to rich medium. Under these conditions, RP gene transcription is greatly upregulated (68), and splicing of newly synthesized transcripts can be assayed. In contrast to wild type, in which unspliced precursor is never observed (e.g., Figure 9B, lanes 2 and 3), ctkl $1 \Delta$ cells consistently contain significant amounts of the unspliced RPS17A transcript (lanes 5 and 6). These results provide strong support for the idea that interactions between one or more of the above listed splicing factors and the CTDK-I-generated PCTD are important for splicing in vivo.

\section{Functional Organization of PCAPs and Associated Proteins}

The far-western analysis on the 2,5P elutions in Figure 7C-E indicates that not all proteins present bind the PCTD probe directly, implying that some of the proteins associate with the peptide column indirectly. We therefore asked whether any of the proteins eluting from the 2,5P columns have been previously known to copurify or otherwise associate with each other. A search of recent proteomic analyses from yeast $(69,70)$ revealed that the majority of proteins that we found on the peptide columns (listed in Figure 8) have indeed been shown previously to copurify with others on the columns. PCAPs and associated proteins that have previously been found together in a complex are listed in Table 1 of the Supporting Information, categorized by either the complex number from ref 70 or the "bait" protein from ref 69. Interestingly, not all proteins from any given complex were found on our columns; for example, of the 46 proteins comprising complex number 132 as described in ref 70, we found only 9 (Brx1, Cbf5, Has1, Mis1, Mrp7, Upt20, Cic1, Fun12, Noc2); some were purified from "middle" P11 fractions and some from "late" P11 fractions. Similar profiles were observed for almost all such complexes as described in either ref 70 or ref 69 (see Table 1 of Supporting Information and Discussion). Intriguingly, in addition to such physical interactions, these proteins also interact with each other genetically [SGD, Saccharomyces Genome Database, http://www.yeastgenome.org/ $(58,71,72)]$, indicating that the observed physical interactions also have functional significance in vivo (Table 2 of Supporting Information). In addition, several of the proteins have been found to interact genetically with genes encoding transcription elongation-related functions, such as $C D C 73(58,71,72)$. Moreover, such genes encoding transcription elongation-related functions (e.g., $C D C 73$ ) in their turn interact genetically with CTK1 (71-73). Taken together, the new and extant data support the idea that the physical interactions between these proteins are functionally significant in the context of CTD phosphorylation and/or transcription elongation.

\section{DISCUSSION}

\section{General Strategy for Identifying PhosphoCTD-Associating Proteins (PCAPs)}

We describe a systematic biochemical search of the yeast proteome for proteins that associate with the phosphoCTD generated by CTD kinase I. This search successfully uncovered a large number of new PCAPs and associated proteins, most of which likely interact with Pol II in the elongation phase of transcription. We chose a biochemical approach because past genetic selections and two-hybrid screens had met with limited success in identifying PCTDassociating proteins. Genetic selection for suppression of CTD truncations, for example, yielded factors involved in initiation (when the CTD is hypophosphorylated) but not in elongation or later phases of transcription (74,75). Furthermore, two-hybrid screens for CTDinteracting factors produced only a small number of proteins (76-79). Even a technically 
refined version of the two-hybrid method recently uncovered only a few candidates, and it failed to find known PCAPs (80).

Our purification approach employed a combination of ionexchange chromatography, affinity chromatography, and far-western blotting. We optimized extraction of proteins likely to be associated with hyperphosphorylated, template-engaged Pol II by using buffers of high ionic strength, and we enriched for PCAPs by subjecting such extracts to cation-exchange chromatography. Our choice of stringent extraction and purification conditions was predicated on the supposition that such treatments would dissociate electrostatically weak interactions within macromolecular complexes; we hoped thereby to purify the "core" PCTD-associated proteome.

In the initial iterations of our search (methods 1 and 2), fractions from ion-exchange chromatography steps were applied to affinity columns carrying a CTD fusion protein exhaustively phosphorylated by CTDK-I. This led to the identification of a number of novel PCAPs, and an analysis of recombinant versions of several of these proteins both validated the overall approach and bore out the specificity of the PCTD far-western assay: these PCAPs (Ssd1, Set2, Hrr25, Ess1) apparently display little or no affinity for CTDs without phosphate groups. Also, these PCAPs appear to bind best to CTD repeats phosphorylated on Ser2 and Ser5 of the heptad repeats, the pattern thought to be generated by CTDK-I (32). In view of this, later iterations of our search employed affinity matrices made from synthetic peptides carrying phosphorylated serines at repeat positions 2 and 5. Using the peptide columns, in combination with other technical improvements, resulted in isolation of a large number of PCAPs and associated proteins, discussed more below.

\section{PCAPs Bind Doubly Phosphorylated CTD Repeats}

Using SPR, we characterized the binding of a subset of PCAPs to various synthetic CTD-repeat phosphopeptides; as mentioned, we find that all proteins thus examined preferentially bind CTD repeats doubly phosphorylated at both serines 2 and 5 of each heptad, consistent with the positional specificity of CTDK-I in vitro (32). When we used such doubly phosphorylated synthetic CTD peptides as affinity matrices to expand our PCAP search, we found that PCAPs (proteins that bind to the CTDK-I-generated PCTD in a far-western assay) were indeed selectively enriched on the doubly phosphorylated CTD peptide column. Furthermore, the farwestern profile of proteins eluted from a doubly phosphorylated CTD peptide column recapitulates that of proteins eluted from a PCTD column. In view of these data, as well as those presented in ref 32 , we think it likely that the exhaustively phosphorylated PCTD generated by CTDK-I in vitro carries doubly (on both serines 2 and 5) phosphorylated heptad repeats.

Might there then be doubly phosphorylated heptad repeats on the CTD of transcribing Pol II in vivo? CTD phosphorylation patterns during the transcription cycle have traditionally been assayed in chromatin immunoprecipitation (ChIP) experiments using the commercially available monoclonal antibodies $\mathrm{H} 14$ and $\mathrm{H} 5$, ostensibly specific for serine 5 and serine 2 phosphorylation, respectively. H14 epitopes are usually prevalent at promoters but decrease as Pol II transcribes into the coding regions of genes, where H5 epitopes predominate $(3,16)$. A common conclusion drawn from these observations is that the CTD is phosphorylated on serine 5 at or near the promoter, while CTD repeats on elongating Pol II carry their phosphates on serine 2 but not serine 5 . Notwithstanding the fact that the specificities of these antibodies may not in fact be as unambiguous as widely supposed $(8,16,32)$ and that their epitopes might be masked by (P)CTD-bound factors, serine 5 phosphorylation is also detected in the coding regions of genes. Along the yeast PMAl gene, for example, the H14 epitope is detected at levels $30-40 \%$ of those found at the promoter (4), minimally implying that elongating Pol II carries phosphates on both serines 2 and 5 of the CTD. In further support of this idea, and 
attesting perhaps to its applicability in other organisms, ChIP and polytene chromosome immunoflourescence experiments with the active Drosophila hsp 70 gene show that the ratio of serine 5 phosphorylation to total Pol II remains constant across the gene, while the H5 epitope, which increases toward the $3^{\prime}$ end, is also present throughout the gene (5). Thus, although extant data do not permit an unequivocal assignment of CTD phosphorylation patterns during transcription, one may reasonably assume that the CTD of elongating Pol II carries phosphates on both serines 2 and 5 of the heptad repeats. Whether such phosphates exist concurrently on the same heptad and are the actual determinants of PCAP binding specificity in vivo are questions we are currently investigating.

\section{PCAPs and Their PhosphoCTD-Interacting Domains (PC-IDs): Functional Implications for CTD Phosphorylation by CTDK-I}

The PCAPs we have characterized in most detail preferentially bind CTD repeats phosphorylated at both serines 2 and 5 of each heptad, consistent with the positional specificity of CTDK-I in vitro (32). We hypothesize that CTD phosphorylation by CTDK-I plays a significant role in the processes mediated by these PCAPs. This hypothesis is afforded support by recent results from several laboratories, in addition to being supported by our data.

\section{(1) Ssd1, Prp40, and Pre-mRNA Splicing}

Ssd1 is thought to be involved in diverse cellular pathways implicated in cell growth and differentiation (e.g., refs 46-48,50,52-54, and 81); of particular relevance in the current context is its apparent role in pre-mRNA processing $(52,56)$. That the $\mathrm{N}$-terminal 160 amino acids of Ssd1 bind the phosphoCTD is interesting in the light of genetic complementation studies using Ssd1 deletion constructs, which indicate that both the RNase II homology region and the Nterminal 160 amino acids are essential for its function $(47,57)$. In fact, the $s s d l-d$ allele codes for a truncated version of the protein lacking the RNase II homology domain but including the PCID (53). Ssd1 has also been shown to be RNA-associated in vivo (49). One possibility is that its association with the phosphoCTD of elongating Pol II targets Ssd1 to its cognate RNAs in the cell, much as the association with the PCTD is thought to target the splicing factor Prp40 (34). It is also conceivable that Ssd1 performs additional functions in the cell independent of its phosphoCTD association. This would be consistent with the finding that Ssd1 can be found both in the nucleus and in the cytoplasm (49). Functions of Ssd1 independent of the phosphoCTD made by CTDK-I would also help to explain phenotypes displayed by various $s s d l$ and $c t k l$ mutants. For example, the fact that a deletion of $S S D l$ is synthetically lethal with a deletion of CTK1 implies that Ssd1 does not function just through a pathway involving CTDK-I. Also, the splicing defect in a $c t k l \Delta$ strain is much worse than that in an $s s d l \Delta$ strain (H. P. Phatnani and A. L. Greenleaf, unpublished results), even though Ssd1 is a general splicing mutant suppressor (52). Finally, Ssd1 is postulated to be in one of the pathways regulating cell wall integrity (54), yet $c t k l \Delta$ mutants are not sensitive to Calcoflour White $(\mathrm{H}$. P. Phatnani and A. L. Greenleaf, unpublished results).

The identification of both the splicing factor Prp40 and the general splicing mutant suppressor Ssd 1 as PCAPs motivated us to test whether splicing might be affected in $c t k l$ mutants. We found that $c t k 1 \Delta$ mutants are indeed defective in the splicing of the newly synthesized RPS17A transcript, which is thought to be cotranscriptionally spliced very efficiently $(82,83)$. In fact, under our assay conditions, we have never observed unspliced RPS17A pre-mRNA in wild-type cells. This is the first demonstration of an in vivo splicing defect for any CTD kinase mutant in yeast, and we believe it can be attributed specifically to the loss of CTDK-I-generated PCTD. 


\section{(2) Set2 and Histone Methylation}

The SET domain-containing protein Set2 has recently been shown by several groups to interact with the phosphorylated form of RNA polymerase II both in vitro and in vivo $(37,38,58-64)$. Set 2 is a histone methyltransferase that methylates lysine 36 of histone H3; its catalytic activity resides in its SET domain. C-Terminal to the SET domain, Set2 also has a WW domain and a predicted coiled-coil domain (SMART domain database, http://smart.embl-heidelberg.de/). Dissecting the non-SET domain part of the protein led to finding a region at the extreme carboxyl-terminal end of Set2 (amino acids 619-733) that binds directly to the CTDK-Igenerated PCTD in vitro [termed the SRI region (65)]. In support of a functional role for the C-terminal 115 amino acids in PCTD binding in vivo, a deletion of this region abolishes the ability of Set2 to immunoprecipitate Pol IIO, and it eliminates methylation uniquely of lysine 36 of histone H3 (65). Correspondingly, deletion of CTK1 also results in the specific loss of H3 lysine 36 methylation (37).

In addition, we have shown that a construct containing the WW domain of Set 2 can also bind specifically and directly to the CTDK-I-generated PCTD in vitro (see Figure 4C). Set2 thus appears to have at least two regions which can bind directly to the PCTD. Although it remains to be determined whether its WW domain plays a role in tethering Set2 to elongating Pol II in vivo, it will be interesting to see whether, in addition to abolishing lysine 36 methylation, a deletion of the SRI region also always abolishes the recruitment of Set 2 to actively transcribed genes.

\section{(3) Hrr25 and DNA Transactions}

Hrr25 is an isoform of casein kinase I (CKI) which physically interacts with and phosphorylates Swi6; it is involved in mediating the tran-scriptional response to DNA damage caused by methyl methanesulfonate (MMS) or treatment with hydroxyurea (HU) (66,84). Specifically, $h r r 25 \Delta$ cells were shown to be defective in the transcriptional induction of $R N R$ gene expression upon exposure to $\mathrm{HU}(66)$; fittingly, $c t k 1 \Delta$ cells display the same defect in DNA damage responses (67).

Consistent with its ability to bind the CTDK-I-generated PCTD, Hrr25 has also been phenomenologically linked to transcription elongation by Pol II by virtue of its involvement in the zymocin sensitivity pathway. Susceptibility to this KluyVeromyces lactis toxin appears to be intricately woven with proper CTD phosphorylation in the context of elongating Pol II (85-93); truncation of the CTD or absence of any of the four CTD kinases results in zymocin hypersen-sitivity, while overexpression of the CTD phosphatase Fcp1 confers zymocin resistance $(89,90,92)$. Resistance to zymocin is also conferred by mutations in Hrr25: either mutation of its catalytic domain or a deletion of the C-terminal 100 amino acids of $\operatorname{Hrr} 25$ is sufficient to confer zymocin resistance. Interestingly, deletion of this C-terminal region of Hrr25 appears to genetically dissociate MMS sensitivity from zymocin resistance, since such mutants display normal vulnerability to MMS but are still resistant to zymocin (86). Although the function of this C-terminal region is still unknown, yeast Hrr25 resembles a subset of CKI family members found in higher organisms that carry an $\mathrm{N}$-terminal protein kinase domain attached to a similar C-terminal extension (94). It may be that for this class of CKI proteins the $\mathrm{C}$-terminal extension harbors another functionality, namely, phosphoCTD binding.

\section{Optimizing PCAP Purification}

Exploiting the finding that PCAPs preferentially bind doubly phosphorylated CTD repeats, we revised our PCAP purification strategy to include affinity chromatography on such doubly phosphorylated CTD peptide matrices. We also optimized initial extraction and fractionation conditions to maximize both efficiency of purification and yield of PCAPs. We used buffers of sufficiently high ionic strength to likely dissociate factors associated with template-engaged 
Pol II and enriched for phosphoCTD-associating proteins by subjecting the resulting extract to ion-exchange chromatography on a P11 cellulose phosphate resin. PCAPs from P11 fractions were then affinity purified using synthetic CTD phosphopeptides. Far-western analysis showed that proteins that bind the CTDK-I-gener-ated PCTD are best enriched on an affinity matrix carrying a CTD peptide that is doubly phosphorylated on each heptad. Consistent with their specificity in the BIACORE (SPR) analysis, Ssd1, Hrr25, Set2, and Ess1 all bind the doubly phosphorylated CTD peptide column, verifying the validity of this approach as a general strategy for purifying proteins that associate with the CTDK-I-generated phosphoCTD.

\section{PCAPs and Associated Proteins from P11 Fractions: Expanding the Functional Repertoire of Elongating Pol II}

The above modifications to our purification strategy dramatically increased the number of PCAPs and associated proteins we were ultimately able to isolate and identify. Figure 8 lists all of the approximately 100 proteins that were so identified, grouped into functional categories on the basis of extant information [largely culled from the Saccharomyces Genome Database (SGD), http://www.yeastgenome.org/]. The functional categories are semiarbitrary, since many of the proteins have been implicated in more than one process. For example, Mrt4, mutations in which are defective for normal mRNA turnover, has also been implicated in biogenesis of the large ribosomal subunit $(95,96)$. Mutations in Vps16, which is annotated as being involved in vacuolar biogenesis, also lead to defects in mRNA turnover (97-102). Another case in point is Cbf5. Originally identified as a low-affinity centromere binding factor (103), Cbf5 is believed to be a pseudouridine synthase and has, in fact, been shown to be an integral component of box H/ACA snoRNPs (104-106). Intriguingly, another component of such snoRNPs has recently been shown to be able to interact with the phosphorylated CTD (107), providing another link between snoRNP biogenesis and elongating Pol II. Altogether, our data reveal physical connections between the PCTD and proteins with an unexpectedly broad array of functions. We suggest that our results manifest heretofore unsuspected or undocumented links between a multitude of nuclear processes and Pol II and that they predict new roles for the phospho-CTD. Given the proteins listed in Figure 8, such new roles would include participation in several aspects of DNA metabolism, multiple facets of chromatin structure modulation, events of protein synthesis and/or turnover (also see refs 108 and 109), RNA degradation, snRNA modification, and snoRNP biogenesis.

A comparison of the far-western and staining profiles of proteins eluted from the 2,5P peptide columns reveals that many proteins retained on the columns do not bind the PCTD directly. Presumably such proteins interact with the PCTD by virtue of associating with a directly binding partner. We therefore asked whether any of the proteins eluting from the peptide columns have been previously known to copurify or otherwise associate with each other. A search of recent proteomic analyses from yeast $(69,70)$ revealed that the majority of proteins that we found on the peptide columns (listed in Figure 8) have indeed been shown previously to copurify with others on the columns. PCAPs and associated proteins that have previously been found together in a complex are listed in Table 1 of the Supporting Information. Interestingly, we found only a subset of proteins from any given complex; for instance, just 9 of a total of 46 proteins from complex number 132 of ref 70 were found on our columns. Five of the 9 proteins were purified from middle P11 fractions, while the other 4 were purified from late fractions. This pattern was repeated for almost all of the complexes; in some cases, the same proteins were purified more than once from different sets of P11 fractions. For example, of the 7 proteins (of a total of 31) from complex number 137 of ref 70, Abf2, Isw1, and Top1 were purified from "early" P11 fractions. Abf2, Isw1, and Top1, along with Cka1 and Ume6, were also purified from middle P11 fractions, and Ume 6 and Cka1 in turn were purified along with $\mathrm{Cka} 2$ and $\mathrm{Hta} 2$ from late $\mathrm{P} 11$ fractions. In light of this kind of behavior, it is tempting to 
speculate that the stringency of our conditions resulted in disruption of weakly associated complexes and the purification of tightly associated core subcomplexes.

In this regard it is interesting that $\mathrm{Cdc} 73$ and $\mathrm{Ctr} 9$ were found on the doubly phosphorylated peptide column. These two proteins are components of the Paf 1 complex which associates with transcriptionally active genes (110). This complex was originally postulated to bind to the body of Pol II, independent of the CTD (43). Therefore, CTD phosphorylation may not play a role in their recruitment; this is consistent with recent data indicating that $\mathrm{Ctr} 9$ and other Paf1 components can be cross-linked to genes independent of Ctk1 (4). However, our results suggest that $\mathrm{Cdc} 73$ and/or Ctr9 may either bind the PCTD themselves or associate with another protein that can bind the PCTD. This possibility is consistent with the finding that $c d c 73 \Delta$ is synthetically lethal with $c t k 1 \Delta$ (e.g., ref 73), suggesting that the two gene products combine to provide an essential function.

A surprising number of the proteins eluting from the phosphopeptide columns are involved in processes whose link to the PCTD does not readily admit intuitive understanding. However, this situation may be largely explained by our very incomplete knowledge of both the multifunctional nature of proteins in general (111-113) and the functional organization of the nucleus in particular. That the observed physical interactions likely do have functional significance in vivo is implied by the number of genetic interactions between or among PCAPs and associated proteins [SGD $(58,71,72)$ and Table 2 of Supporting Information]. These genetic interactions are reminiscent of those typifying Ctk1 and the subset of PCAPs described earlier: Set2, Ssd1, and Hrr25. Thus, while proving the physiological significance of the observed interactions requires further experiments, we suggest that in many cases the in vivo relevance of the newly uncovered associations will be borne out.

A speculative model based on our findings is presented in Figure 10. Our results indicate that there are a large number of proteins that can bind the PCTD directly or indirectly. A significant number of such proteins and/or protein complexes could conceivably be accommodated on the PCTD simultaneously, given the length of the CTD and its likely extended nature when phosphorylated (114). Although the placement of the proteins and complexes on the PCTD is not known, and is arbitrary in the figure, it will be interesting in the future to determine if a given PCAP always binds the PCTD at a preferred location. While the actual three-dimensional disposition of the PCTD in vivo is not known, it is long enough to potentially position PCAPs and associated factors to act both on the chromatin/DNA either upstream or downstream of the transcribing polymerase and on different segments of the nascent transcript.

\section{SUMMARY}

A biochemical search of the yeast proteome identified a large number of proteins with physical connections to the CTD kinase I-generated phosphoCTD of RNA Pol II. Characterization of some of these phosphoCTD-associating proteins (PCAPs), taken together with enzymatic analysis of CTDK-I itself (32), suggests that elongating Pol II carries a CTD with doubly phosphorylated heptad repeats (phosphate groups on both Ser2 and Ser5). Furthermore, genetic and biochemical analyses of a few of the PCAPs (notably, Set2, Ssd1, and Hrr25) imply that the physical connections between the PCTD and most of the newly identified proteins have functional significance in vivo. The range of functions with implied connections to the PCTD greatly exceeds expectations. We suggest that, beyond its known participation in RNA processing, the functional repertoire of elongating Pol II includes roles in DNA metabolism, chromatin structure modulation, protein synthesis and turnover, RNA degradation, snRNA modification, and snoRNP biogenesis (see Figure 10). 


\section{Supplementary Material}

Refer to Web version on PubMed Central for supplementary material.

\section{Acknowledgments}

We thank Munir Alam for help with the BIACORE analysis, Brian Strahl and Kelby Kizer for unpublished information on Set2, Peter Cook and John Woolford for helpful discussions, and Ken Greenleaf for Figure 10 and the table of contents graphic.

\section{REFERENCES}

1. Dahmus ME. Reversible phosphorylation of the C-terminal domain of RNA polymerase II. J. Biol. Chem 1996;271:19009-19012. [PubMed: 8759772]

2. Dahmus ME. Phosphorylation of the C-terminal domain of RNA polymerase II. Biochim. Biophys Acta 1995;1261:171-182. [PubMed: 7711060]

3. Komarnitsky P, Cho EJ, Buratowski S. Different phosphorylated forms of RNA polymerase II and associated mRNA processing factors during transcription. Genes DeV 2000;14:2452-2460. [PubMed: 11018013]

4. Ahn SH, Kim M, Buratowski S. Phosphorylation of serine 2 within the RNA polymerase II C-terminal domain couples transcription and 3' end processing. Mol. Cell 2004;13:67-76. [PubMed: 14731395]

5. Boehm AK, Saunders A, Werner J, Lis JT. Transcription factor and polymerase recruitment, modification, and movement on dhsp70 in vivo in the minutes following heat shock. Mol. Cell. Biol 2003;23:7628-7637. [PubMed: 14560008]

6. Rodriguez CR, Cho EJ, Keogh MC, Moore CL, Greenleaf AL, Buratowski S. Kin28, the TFIIHassociated carboxy-terminal domain kinase, facilitates the recruitment of mRNA processing machinery to RNA polymerase II. Mol. Cell. Biol 2000;20:104-112. [PubMed: 10594013]

7. Schroeder SC, Schwer B, Shuman S, Bentley D. Dynamic association of capping enzymes with transcribing RNA polymerase II. Genes DeV 2000;14:2435-2440. [PubMed: 11018011]

8. Licatalosi DD, Geiger G, Minet M, Schroeder S, Cilli K, McNeil JB, Bentley DL. Functional interaction of yeast pre-mRNA 3' end processing factors with RNA poly-merase II. Mol. Cell 2002;9:1101-1111. [PubMed: 12049745]

9. Sudol M, Sliwa K, Russo T. Functions of WW domains in the nucleus. FEBS Lett 2001;490:190-195. [PubMed: 11223034]

10. Hengartner CJ, Myer VE, Liao SM, Wilson CJ, Koh SS, Young RA. Temporal regulation of RNA polymerase II by Srb10 and Kin28 cyclin-dependent kinases. Mol. Cell 1998;2:43-53. [PubMed: 9702190]

11. Liao SM, Zhang J, Jeffery DA, Koleske AJ, Thompson CM, Chao DM, Viljoen M, van Vuuren HJ, Young RA. A kinase-cyclin pair in the RNA polymerase II holoenzyme. Nature 1995;374:193-196. [PubMed: 7877695]

12. Liu Y, Kung C, Fishburn J, Ansari AZ, Shokat KM, Hahn S. Two cyclin-dependent kinases promote RNA polymerase II transcription and formation of the scaffold complex. Mol. Cell. Biol 2004;24:1721-1735. [PubMed: 14749387]

13. Keogh MC, Podolny V, Buratowski S. Bur1 kinase is required for efficient transcription elongation by RNA poly-merase II. Mol. Cell. Biol 2003;23:7005-7018. [PubMed: 12972617]

14. Prelich G. RNA polymerase II carboxy-terminal domain kinases: Emerging clues to their function. Eukaryotic Cell 2002;1:153-162. [PubMed: 12455950]

15. Murray S, Udupa R, Yao S, Hartzog G, Prelich G. Phosphorylation of the RNA polymerase II carboxyterminal domain by the Bur1 cyclin-dependent kinase. Mol. Cell. Biol 2001;21:4089-4096. [PubMed: 11390638]

16. Cho EJ, Kobor MS, Kim M, Greenblatt J, Buratowski S. Opposing effects of Ctk1 kinase and Fcp1 phosphatase at Ser 2 of the RNA polymerase II C-terminal domain. Genes DeV 2001;15:3319-3329. [PubMed: 11751637] 
17. Lee JM, Greenleaf AL. Modulation of RNA polymerase II elongation efficiency by C-terminal heptapeptide repeat domain kinase I. J. Biol. Chem 1997;272:10990-10993. [PubMed: 9110987]

18. Lee JM, Greenleaf AL. CTD kinase large subunit is encoded by CTK1, a gene required for normal growth of Saccharomyces cerevisiae. Gene Expression 1991;1:149-167. [PubMed: 1820212]

19. Costa PJ, Arndt KM. Synthetic lethal interactions suggest a role for the Saccharomyces cerevisiae Rtf1 protein in transcription elongation. Genetics 2000;156:535-547. [PubMed: 11014804]

20. Lindstrom DL, Hartzog GA. Genetic interactions of Spt4-Spt5 and TFIIS with the RNA polymerase II CTD and CTD modifying enzymes in Saccharomyces cerevisiae. Genetics 2001;159:487-497. [PubMed: 11606527]

21. Jona G, Wittschieben BO, Svejstrup JQ, Gileadi O. Involvement of yeast carboxy-terminal domain kinase I (CTDK-I) in transcription elongation in vivo. Gene 2001;267:31-36. [PubMed: 11311553]

22. Wilcox CB, Rossettini A, Hanes SD. Genetic interactions with C-terminal domain (CTD) kinases and the CTD of RNA Pol II suggest a role for ESS1 in transcription initiation and elongation in Saccharomyces cerevisiae. Genetics 2004;167:93-105. [PubMed: 15166139]

23. Chambers RS, Dahmus ME. Purification and characterization of a phosphatase from HeLa cells which dephos-phorylates the C-terminal domain of RNA polymerase II. J. Biol. Chem 1994;269:2624326248. [PubMed: 7929341]

24. Chambers RS, Kane CM. Purification and characterization of an RNA polymerase II phosphatase from yeast. J. Biol. Chem 1996;271:24498-24504. [PubMed: 8798710]

25. Kobor MS, Archambault J, Lester W, Holstege FC, Gileadi O, Jansma DB, Jennings EG, Kouyoumdjian F, Davidson AR, Young RA, Greenblatt J. An unusual eukaryotic protein phosphatase required for transcription by RNA polymerase II and CTD dephosphorylation in S. cerevisiae. Mol. Cell 1999;4:55-62. [PubMed: 10445027]

26. Krishnamurthy S, He X, Reyes-Reyes M, Moore C, Hampsey M. Ssu72 Is an RNA polymerase II CTD phosphatase. Mol. Cell 2004;14:387-394. [PubMed: 15125841]

27. Licciardo P, Ruggiero L, Lania L, Majello B. Transcription activation by targeted recruitment of the RNA polymerase II CTD phosphatase FCP1. Nucleic Acids Res 2001;29:3539-3545. [PubMed: 11522823]

28. Friedl EM, Lane WS, Erdjument-Bromage H, Tempst P, Reinberg D. The C-terminal domain phosphatase and transcription elongation activities of FCP1 are regulated by phosphorylation. Proc. Natl. Acad. Sci. U.S.A 2003;100:2328-2333. [PubMed: 12591939]

29. Ganem C, Devaux F, Torchet C, Jacq C, Quevillon-Cheruel S, Labesse G, Facca C, Faye G. Ssu72 is a phosphatase essential for transcription termination of snoRNAs and specific mRNAs in yeast. EMBO J 2003;22:1588-1598. [PubMed: 12660165]

30. He X, Khan AU, Cheng H, Pappas DL Jr, Hampsey M, Moore CL. Functional interactions between the transcription and mRNA 3' end processing machineries mediated by Ssu72 and Sub1. Genes DeV 2003;17:1030-1042. [PubMed: 12704082]

31. Steinmetz EJ, Brow DA. Ssu72 protein mediates both poly(A)-coupled and poly(A)-independent termination of RNA polymerase II transcription. Mol. Cell. Biol 2003;23:6339-6349. [PubMed: 12944462]

32. Jones JC, Phatnani HP, Haystead TA, MacDonald JA, Alam SM, Greenleaf AL. C-terminal repeat domain kinase I phosphorylates Ser2 and Ser5 of RNA polymerase II C-terminal domain repeats. J. Biol. Chem 2004;279:24957-24964. [PubMed: 15047695]

33. Ni Z, Schwartz BE, Werner J, Suarez JR, Lis JT. Coordination of transcription, RNA processing, and surveillance by P-TEFb kinase on heat shock genes. Mol. Cell 2004;13:55-65. [PubMed: 14731394]

34. Morris DP, Greenleaf AL. The splicing factor, Prp40, binds the phosphorylated carboxyl-terminal domain of RNA polymerase II. J. Biol. Chem 2000;275:39935-39943. [PubMed: 10978320]

35. Skaar DA, Greenleaf AL. The RNA polymerase II CTD kinase CTDK-I affects pre-mRNA 3' cleavage/polyade-nylation through the processing component Pti1p. Mol. Cell 2002;10:1429-1439. [PubMed: 12504017]

36. Morris DP, Phatnani HP, Greenleaf AL. Phospho-carboxyl-terminal domain binding and the role of a prolyl isomerase in pre-mRNA 3'-end formation. J. Biol. Chem 1999;274:31583-31587. [PubMed: 10531363] 
37. Xiao T, Hall H, Kizer KO, Shibata Y, Hall MC, Borchers CH, Strahl BD. Phosphorylation of RNA polymerase II CTD regulates H3 methylation in yeast. Genes DeV 2003;17:654-663. [PubMed: 12629047]

38. Krogan NJ, Kim M, Tong A, Golshani A, Cagney G, Canadien V, Richards DP, Beattie BK, Emili A, Boone C, Shilatifard A, Buratowski S, Greenblatt J. Methylation of histone H3 by Set2 in Saccharomyces cerevisiae is linked to transcriptional elongation by RNA polymerase II. Mol. Cell. Biol 2003;23:4207-4218. [PubMed: 12773564]

39. Carty SM, Greenleaf AL. Hyperphosphorylated C-terminal repeat domain-associating proteins in the nuclear proteome link transcription to DNA/chromatin modification and RNA processing. Mol. Cell. Proteomics 2002;1:598-610. [PubMed: 12376575]

40. Sterner DE, Lee JM, Hardin SE, Greenleaf AL. The yeast carboxyl-terminal repeat domain kinase CTDK-I is a divergent cyclin-cyclin-dependent kinase complex. Mol. Cell. Biol 1995; 15:5716-5724. [PubMed: 7565723]

41. Phatnani HP, Greenleaf AL. Identifying phos-phoCTD-associating proteins. Methods Mol. Biol 2004;257:17-28. [PubMed: 14769993]

42. Woontner M, Wade PA, Bonner J, Jaehning JA. Transcriptional activation in an improved wholecell extract from Saccharomyces cerevisiae. Mol. Cell. Biol 1991;11:4555-4560. [PubMed: 1875938]

43. Wade PA, Werel W, Fentzke RC, Thompson NE, Leykam JF, Burgess RR, Jaehning JA, Burton ZF. A novel collection of accessory factors associated with yeast RNA polymerase II. Protein Expression Purif 1996;8:85-90.

44. Lin, R-J.; Kim, D-H.; Castanotto, SW.; Rossi, JJ. RNA preparations from yeast cells, in A Laboratory Guide to RNA . In: Krieg, PA., editor. Isolation, Analysis, and Synthesis. New York: Wiley-Liss Inc; 1996. p. 43-45.

45. Iyer V, Struhl K. Absolute mRNA levels and transcriptional initiation rates in Saccharomyces cerevisiae. Proc. Natl. Acad. Sci. U.S.A 1996;93:5208-5212. [PubMed: 8643554]

46. Sutton A, Immanuel D, Arndt KT. The SIT4 protein phosphatase functions in late G1 for progression into S phase. Mol. Cell. Biol 1991;11:2133-2148. [PubMed: 1848673]

47. Costigan C, Gehrung S, Snyder M. A synthetic lethal screen identifies SLK1, a novel protein kinase homologue implicated in yeast cell morphogenesis and cell growth. Mol. Cell. Biol 1992;12:11621178. [PubMed: 1545797]

48. Kim YJ, Francisco L, Chen GC, Marcotte E, Chan CS. Control of cellular morphogenesis by the Ip12/ Bem2 GTPase-activating protein: possible role of protein phosphory-lation. J. Cell Biol 1994;127:1381-1394. [PubMed: 7962097]

49. Uesono Y, Toh-e A, Kikuchi Y. Ssd1p of Saccha-romyces cereVisiae associates with RNA. J. Biol. Chem 1997;272:16103-16109. [PubMed: 9195905]

50. Chen CY, Rosamond J. Candida albicans SSD1 can suppress multiple mutations in Saccharomyces cerevisiae. Microbiology 1998;144:2941-2950. [PubMed: 9846729]

51. Moriya H, Isono K. Analysis of genetic interactions between DHH1, SSD1 and ELM1 indicates their involvement in cellular morphology determination in Saccharomyces cerevisiae. Yeast 1999;15:481-496. [PubMed: 10234786]

52. Luukkonen BG, Seraphin B. A conditional U5 snRNA mutation affecting pre-mRNA splicing and nuclear pre-mRNA retention identifies SSD1/SRK1 as a general splicing mutant suppressor. Nucleic Acids Res 1999;27:3455-3465. [PubMed: 10446233]

53. Ibeas JI, Yun DJ, Damsz B, Narasimhan ML, Uesono Y, Ribas JC, Lee H, Hasegawa PM, Bressan RA, Pardo JM. Resistance to the plant PR-5 protein osmotin in the model fungus Saccharomyces cerevisiae is mediated by the regulatory effects of SSD1 on cell wall composition. Plant J 2001;25:271-280. [PubMed: 11208019]

54. Kaeberlein M, Guarente L. Saccharomyces cerevisiae MPT5 and SSD1 function in parallel pathways to promote cell wall integrity. Genetics 2002;160:83-95. [PubMed: 11805047]

55. Li B, Warner JR. Mutation of the Rab6 homologue of Saccharomyces cerevisiae, YPT6, inhibits both early Golgi function and ribosome biosynthesis. J. Biol. Chem 1996;271:16813-16819. [PubMed: 8663225] 
56. Fortes P, Kufel J, Fornerod M, Polycarpou-Schwarz M, Lafontaine D, Tollervey D, Mattaj IW. Genetic and physical interactions involving the yeast nuclear cap-binding complex. Mol. Cell. Biol 1999;19:6543-6553. [PubMed: 10490594]

57. Wilson RB, Brenner AA, White TB, Engler MJ, Gaughran JP, Tatchell K. The Saccharomyces cerevisiae SRK1 gene, a suppressor of bcy1 and ins1, may be involved in protein phosphatase function. Mol. Cell. Biol 1991;11:3369-3373. [PubMed: 1645449]

58. Krogan NJ, Keogh MC, Datta N, Sawa C, Ryan OW, Ding H, Haw RA, Pootoolal J, Tong A, Canadien V, Richards DP, Wu X, Emili A, Hughes TR, Buratowski S, Greenblatt JF. A Snf2 family ATPase complex required for recruitment of the histone H2A variant Htz1. Mol. Cell 2003;12:1565-1576. [PubMed: 14690608]

59. Strahl BD, Grant PA, Briggs SD, Sun ZW, Bone JR, Caldwell JA, Mollah S, Cook RG, Shabanowitz J, Hunt DF, Allis CD. Set2 is a nucleosomal histone H3-selective methyltransferase that mediates transcriptional repression. Mol. Cell. Biol 2002;22:1298-1306. [PubMed: 11839797]

60. Landry J, Sutton A, Hesman T, Min J, Xu RM, Johnston M, Sternglanz R. Set2-catalyzed methylation of histone H3 represses basal expression of GAL4 in Saccharomyces cerevisiae. Mol. Cell. Biol 2003;23:5972-5978. [PubMed: 12917322]

61. Ng HH, Dole S, Struhl K. The Rtf1 component of the Paf1 transcriptional elongation complex is required for ubiquitination of histone H2B. J. Biol. Chem 2003;278:33625-33628. [PubMed: 12876293]

62. Schaft D, Roguev A, Kotovic KM, Shevchenko A, Sarov M, Neugebauer KM, Stewart AF. The histone 3 lysine 36 methyltransferase, SET2, is involved in transcriptional elongation. Nucleic Acids Res 2003;31:2475-2482. [PubMed: 12736296]

63. Li B, Howe L, Anderson S, Yates JR III, Workman JL. The Set2 histone methyltransferase functions through the phosphorylated carboxyl-terminal domain of RNA polymerase II. J. Biol. Chem 2003;278:8897-8903. [PubMed: 12511561]

64. Li J, Moazed D, Gygi SP. Association of the histone methyltransferase Set2 with RNA polymerase II plays a role in transcription elongation. J. Biol. Chem 2002;277:49383-49388. [PubMed: 12381723]

65. Kizer KO, Phatnani HP, Hall H, Greenleaf AL, Strahl BD. A novel domain in Set2 mediates interaction with RNA polymerase II and couples H3 K36 methylation with transcription elongation. Journal (submitted for publication). 2004

66. Ho Y, Mason S, Kobayashi R, Hoekstra M, Andrews B. Role of the casein kinase I isoform, Hrr25, and the cell cycle-regulatory transcription factor, SBF, in the transcriptional response to DNA damage in Saccharomyces cerevisiae. Proc. Natl. Acad. Sci. U.S.A 1997;94:581-586. [PubMed: 9012827]

67. Ostapenko D, Solomon MJ. Budding yeast CTDK-I is required for DNA damage-induced transcription. Eukaryotic Cell 2003;2:274-283. [PubMed: 12684377]

68. Powers T, Walter P. Regulation of ribosome biogenesis by the rapamycin-sensitive TOR-signaling pathway in Saccharomyces cerevisiae. Mol. Biol. Cell 1999;10:987-1000. [PubMed: 10198052]

69. Ho Y, Gruhler A, Heilbut A, Bader GD, Moore L, Adams SL, Millar A, Taylor P, Bennett K, Boutilier K, Yang L, Wolting C, Donaldson I, Schandorff S, Shewnarane J, Vo M, Taggart J, Goudreault M, Muskat B, Alfarano C, Dewar D, Lin Z, Michalickova K, Willems AR, Sassi H, Nielsen PA, Rasmussen KJ, Andersen JR, Johansen LE, Hansen LH, Jespersen H, Podtelejnikov A, Nielsen E, Crawford J, Poulsen V, Sorensen BD, Matthiesen J, Hendrickson RC, Gleeson F, Pawson T, Moran MF, Durocher D, Mann M, Hogue CW, Figeys D, Tyers M. Systematic identification of protein complexes in Saccharomyces cerevisiae by mass spectrometry. Nature 2002;415:180-183. [PubMed: 11805837]

70. Gavin AC, Bosche M, Krause R, Grandi P, Marzioch M, Bauer A, Schultz J, Rick JM, Michon AM, Cruciat CM, Remor M, Hofert C, Schelder M, Brajenovic M, Ruffner H, Merino A, Klein K, Hudak M, Dickson D, Rudi T, Gnau V, Bauch A, Bastuck S, Huhse B, Leutwein C, Heurtier MA, Copley RR, Edelmann A, Querfurth E, Rybin V, Drewes G, Raida M, Bouwmeester T, Bork P, Seraphin B, Kuster B, Neubauer G, Superti-Furga G. Functional organization of the yeast proteome by systematic analysis of protein complexes. Nature 2002;415:141-147. [PubMed: 11805826]

71. Tong AH, Evangelista M, Parsons AB, Xu H, Bader GD, Page N, Robinson M, Raghibizadeh S, Hogue CW, Bussey H, Andrews B, Tyers M, Boone C. Systematic genetic analysis with ordered arrays of yeast deletion mutants. Science 2001;294:2364-2368. [PubMed: 11743205] 
72. Tong AH, Lesage G, Bader GD, Ding H, Xu H, Xin X, Young J, Berriz GF, Brost RL, Chang M, Chen Y, Cheng X, Chua G, Friesen H, Goldberg DS, Haynes J, Humphries C, He G, Hussein S, Ke L, Krogan N, Li Z, Levinson JN, Lu H, Menard P, Munyana C, Parsons AB, Ryan O, Tonikian R, Roberts T, Sdicu AM, Shapiro J, Sheikh B, Suter B, Wong SL, Zhang LV, Zhu H, Burd CG, Munro S, Sander C, Rine J, Greenblatt J, Peter M, Bretscher A, Bell G, Roth FP, Brown GW, Andrews B, Bussey H, Boone C. Global mapping of the yeast genetic interaction network. Science 2004;303:808813. [PubMed: 14764870]

73. Squazzo SL, Costa PJ, Lindstrom DL, Kumer KE, Simic R, Jennings JL, Link AJ, Arndt KM, Hartzog GA. The Paf1 complex physically and functionally associates with transcription elongation factors in vivo. EMBO J 2002;21:1764-1774. [PubMed: 11927560]

74. Thompson CM, Koleske AJ, Chao DM, Young RA. A multisubunit complex associated with the RNA polymerase II CTD and TATA-binding protein in yeast. Cell 1993;73:1361-1375. [PubMed: 8324825]

75. Nonet ML, Young RA. Intragenic and extragenic suppressors of mutations in the heptapeptide repeat domain of Saccharomyces cerevisiae RNA polymerase II. Genetics 1989;123:715-724. [PubMed: 2693207]

76. Yuryev A, Patturajan M, Litingtung Y, Joshi RV, Gentile C, Gebara M, Corden JL. The C-terminal domain of the largest subunit of RNA polymerase II interacts with a novel set of serine/arginine-rich proteins. Proc. Natl. Acad. Sci. U.S.A 1996;93:6975-6980. [PubMed: 8692929]

77. Corden JL, Patturajan M. A CTD function linking transcription to splicing. Trends Biochem. Sci 1997;22:413-416. [PubMed: 9397679]

78. Patturajan M, Wei X, Berezney R, Corden JL. A nuclear matrix protein interacts with the phosphorylated C-terminal domain of RNA polymerase II. Mol. Cell. Biol 1998;18:2406-2415. [PubMed: 9528809]

79. Conrad NK, Wilson SM, Steinmetz EJ, Patturajan M, Brow DA, Swanson MS, Corden JL. A yeast heterogeneous nuclear ribonucleoprotein complex associated with RNA polymerase II. Genetics 2000;154:557-571. [PubMed: 10655211]

80. Guo D, Hazbun TR, Xu XJ, Ng SL, Fields S, Kuo MH. A tethered catalysis, two-hybrid system to identify protein-protein interactions requiring post-translational modifications. Nat. Biotechnol 2004;22:888-892. [PubMed: 15208639]

81. Doseff AI, Arndt KT. LAS1 is an essential nuclear protein involved in cell morphogenesis and cell surface growth. Genetics 1995;141:857-871. [PubMed: 8582632]

82. Elliott DJ, Rosbash M. Yeast pre-mRNA is composed of two populations with distinct kinetic properties. Exp. Cell Res 1996;229:181-188. [PubMed: 8986595]

83. Pikielny CW, Rosbash M. mRNA splicing efficiency in yeast and the contribution of nonconserved sequences. Cell 1985;41:119-126. [PubMed: 3888403]

84. Hoekstra MF, Liskay RM, Ou AC, DeMaggio AJ, Burbee DG, Heffron F. HRR25, a putative protein kinase from budding yeast: association with repair of damaged DNA. Science 1991;253:1031-1034. [PubMed: 1887218]

85. Jablonowski D, Fichtner L, Stark MJ, Schaffrath R. The yeast elongator histone acetylase requires Sit4-dependent dephosphorylation for toxin-target capacity. Mol. Biol. Cell 2004;15:1459-1469. [PubMed: 14718557]

86. Mehlgarten C, Schaffrath R. Mutant casein kinase I (Hrr25p/Kti14p) abrogates the G1 cell cycle arrest induced by KluyVeromyces lactis zymocin in budding yeast. Mol. Genet. Genomics 2003;269:188196. [PubMed: 12756531]

87. Frohloff F, Jablonowski D, Fichtner L, Schaffrath R. Subunit communications crucial for the functional integrity of the yeast RNA polymerase II elongator (gamma-toxin target (TOT)) complex. J. Biol. Chem 2003;278:956-961. [PubMed: 12424236]

88. Fichtner L, Jablonowski D, Schierhorn A, Kitamoto HK, Stark MJ, Schaffrath R. Elongator's toxintarget (TOT) function is nuclear localization sequence dependent and suppressed by posttranslational modification. Mol. Microbiol 2003;49:1297-1307. [PubMed: 12940988]

89. Kitamoto HK, Jablonowski D, Nagase J, Schaffrath R. Defects in yeast RNA polymerase II transcription elicit hypersensitivity to G1 arrest induced by Kluyveromyces lactis zymocin. Mol. Genet. Genomics 2002;268:49-55. [PubMed: 12242498] 
90. Jablonowski D, Schaffrath R. Saccharomyces cerevisiae RNA polymerase II is affected by KluyVeromyces lactis zymocin. J. Biol. Chem 2002;277:26276-26280. [PubMed: 12015322]

91. Fichtner L, Frohloff F, Jablonowski D, Stark MJ, Schaffrath R. Protein interactions within Saccharomyces cerevisiae elongator, a complex essential for Kluyveromyces lactis zymocicity. Mol. Microbiol 2002;45:817-826. [PubMed: 12139626]

92. Jablonowski D, Frohloff F, Fichtner L, Stark MJ, Schaffrath R. Kluyveromyces lactis zymocin mode of action is linked to RNA polymerase II function via elongator. Mol. Microbiol 2001;42:1095-1105. [PubMed: 11737649]

93. Frohloff F, Fichtner L, Jablonowski D, Breunig KD, Schaffrath R. Saccharomyces cerevisiae elongator mutations confer resistance to the Kluyveromyces lactis zymocin. EMBO J 2001;20:19932003. [PubMed: 11296232]

94. Fish KJ, Cegielska A, Getman ME, Landes GM, Virshup DM. Isolation and characterization of human casein kinase I epsilon (CKI), a novel member of the CKI gene family. J. Biol. Chem 1995;270:14875-14883. [PubMed: 7797465]

95. Zuk D, Belk JP, Jacobson A. Temperature-sensitive mutations in the Saccharomyces cerevisiae MRT4, GRC5, SLA2 and THS1 genes result in defects in mRNA turnover. Genetics 1999;153:3547. [PubMed: 10471698]

96. Harnpicharnchai P, Jakovljevic J, Horsey E, Miles T, Roman J, Rout M, Meagher D, Imai B, Guo Y, Brame CJ, Shabanowitz J, Hunt DF, Woolford JL Jr. Composition and functional characterization of yeast 66S ribosome assembly intermediates. Mol. Cell 2001;8:505-515. [PubMed: 11583614]

97. Zhang S, Williams CJ, Hagan K, Peltz SW. Mutations in VPS16 and MRT1 stabilize mRNAs by activating an inhibitor of the decapping enzyme. Mol. Cell. Biol 1999;19:7568-7576. [PubMed: 10523645]

98. Zheng B, Wu JN, Schober W, Lewis DE, Vida T. Isolation of yeast mutants defective for localization of vacuolar vital dyes. Proc. Natl. Acad. Sci. U.S.A 1998;95:11721-11726. [PubMed: 9751732]

99. Paidhungat M, Garrett $\mathrm{S}$. Cdc1 and the vacuole coordinately regulate $\mathrm{Mn}^{2+}$ homeostasis in the yeast Saccharomyces cerevisiae. Genetics 1998;148:1787-1798. [PubMed: 9560393]

100. Rieder SE, Emr SD. A novel RING finger protein complex essential for a late step in protein transport to the yeast vacuole. Mol. Biol. Cell 1997;8:2307-2327. [PubMed: 9362071]

101. Horazdovsky BF, Emr SD. The VPS16 gene product associates with a sedimentable protein complex and is essential for vacuolar protein sorting in yeast. J. Biol. Chem 1993;268:4953-4962. [PubMed: 8444873]

102. Dulic V, Riezman H. Saccharomyces cerevisiae mutants lacking a functional vacuole are defective for aspects of the pheromone response. J. Cell Sci 1990;97(Part 3):517-525. [PubMed: 2074270]

103. Jiang W, Middleton K, Yoon HJ, Fouquet C, Carbon J. An essential yeast protein, CBF5p, binds in vitro to centromeres and microtubules. Mol. Cell. Biol 1993;13:4884-4893. [PubMed: 8336724]

104. Lafontaine DL, Bousquet-Antonelli C, Henry Y, Caizergues-Ferrer M, Tollervey D. The box H + ACA snoRNAs carry Cbf5p, the putative rRNA pseudouridine synthase. Genes Dev 1998;12:527537. [PubMed: 9472021]

105. Watkins NJ, Gottschalk A, Neubauer G, Kastner B, Fabrizio P, Mann M, Luhrmann R. Cbf5p, a potential pseudouridine synthase, and Nhp2p, a putative RNA-binding protein, are present together with Garlp in all H BOX/ACA-motif snoRNPs and constitute a common bipartite structure. RNA 1998;4:1549-1568. [PubMed: 9848653]

106. Zebarjadian Y, King T, Fournier MJ, Clarke L, Carbon J. Point mutations in yeast CBF5 can abolish in vivo pseudouridylation of rRNA. Mol. Cell. Biol 1999;19:7461-7472. [PubMed: 10523634]

107. Fatica A, Dlakic M, Tollervey D. Naf1 p is a box H/ACA snoRNP assembly factor. RNA 2002;8:1502-1514. [PubMed: 12515383]

108. Iborra FJ, Escargueil AE, Kwek KY, Akoulitchev A, Cook PR. Molecular cross-talk between the transcription, translation, and nonsense-mediated decay machineries. J. Cell Sci 2004;117:899-906. [PubMed: 14762111]

109. Mangiarotti G. Coupling of transcription and translation in Dictyostelium discoideum nuclei. Biochemistry 1999;38:3996-4000. [PubMed: 10194311]

110. Pokholok DK, Hannett NM, Young RA. Exchange of RNA polymerase II initiation and elongation factors during gene expression in vivo. Mol. Cell 2002;9:799-809. [PubMed: 11983171] 
111. Wool IG. Extraribosomal functions of ribosomal proteins. Trends Biochem. Sci 1996;21:164-165. [PubMed: 8871397]

112. Zimmermann RA. The double life of ribosomal proteins. Cell 2003;115:130-132. [PubMed: 14567909]

113. Jeffery CJ. Moonlighting proteins: old proteins learning new tricks. Trends Genet 2003;19:415417. [PubMed: 12902157]

114. Zhang J, Corden JL. Phosphorylation causes a conformational change in the carboxyl-terminal domain of the mouse RNA polymerase II largest subunit. J. Biol. Chem 1991;266:2297-2302. [PubMed: 1989983] 


\section{Method 1}

Method 2

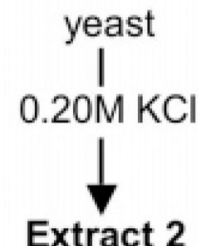

Extract 1

$\frac{1}{\checkmark}$

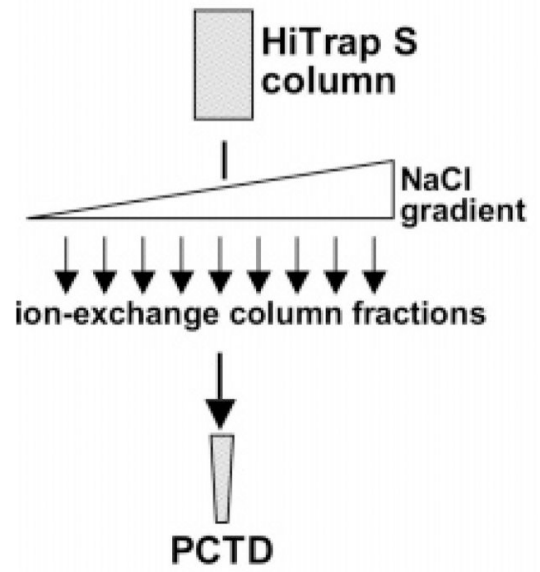

$\downarrow$
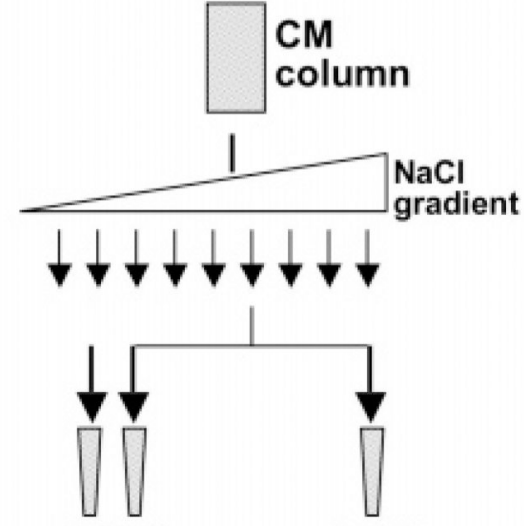

PCTD
Method 3

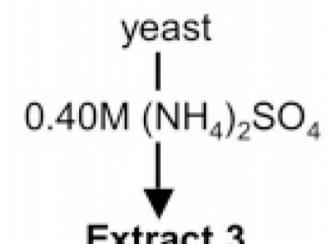

Extract 3
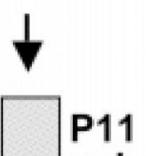
column
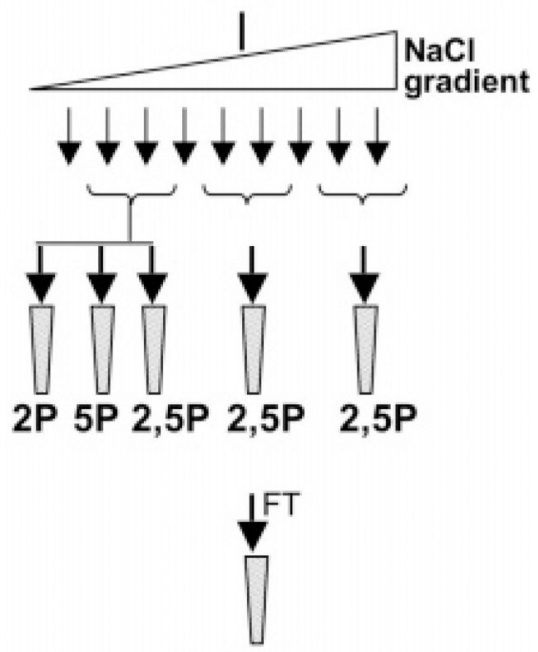

$2,5 \mathrm{P}$

FIGURE 1.

Schematic overview of methods used to purify phosphoCTD-associating proteins (PCAPs) from yeast. Rectangles represent ion-exchange columns; triangles represent salt elution gradients; trapezoids represent affinity columns. 
A

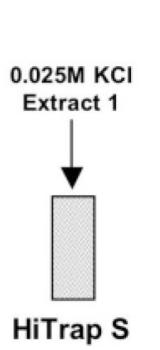

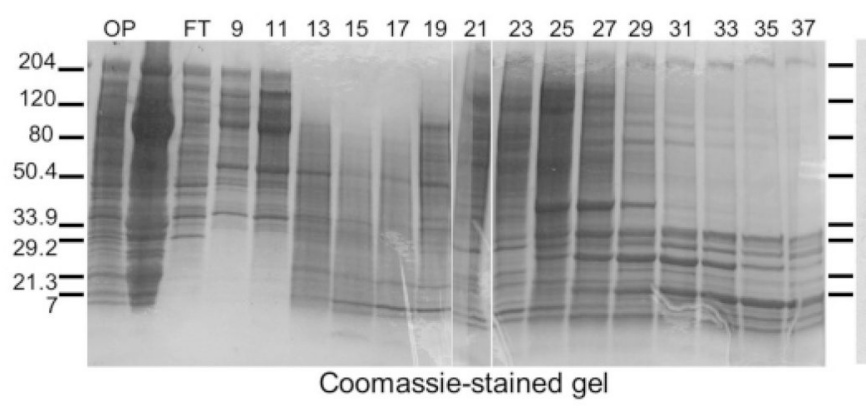

B

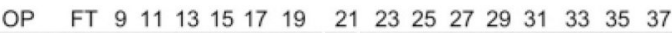
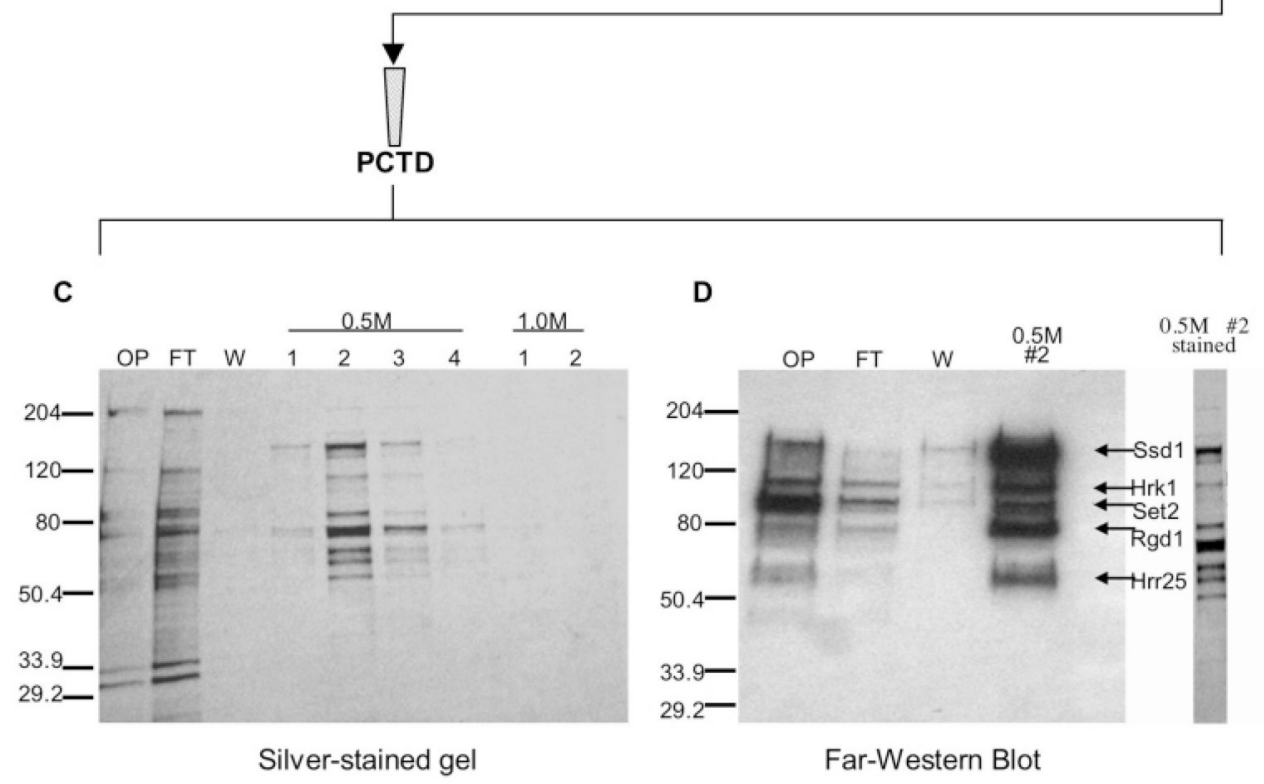

FIGURE 2.

PCAP purification by method 1 (details in Materials and Methods). HiTrap S fractions subjected to SDS-PAGE were stained with Coomassie Blue (A) or analyzed by far-western blotting (B) with $\beta$-gal- $\left[{ }^{32} \mathrm{P}\right] \mathrm{PCTD}$ fusion protein as probe [OP )onput, FT ) flow-through]. Proteins in HiTrap S fraction 23 were further fractionated on a $100 \mu L$ phosphoCTD affinity column. Aliquots of the onput (OP), flow-through (FT), wash (W), and 0.5 and $1.0 \mathrm{M}$ salt step elution fractions were analyzed by SDS-PAGE and stained with silver (C). Corresponding aliquots were analyzed by far-western blotting with GST-PCTD as probe (D) (detected using affinity-purified anti-GST antibody). On the right is shown a silver-stained lane of the $0.5 \mathrm{M}$ \#2 sample. The identities of PCAPs 1 - 5 are listed alongside the respective bands. Symbols are as in Figure 1. 


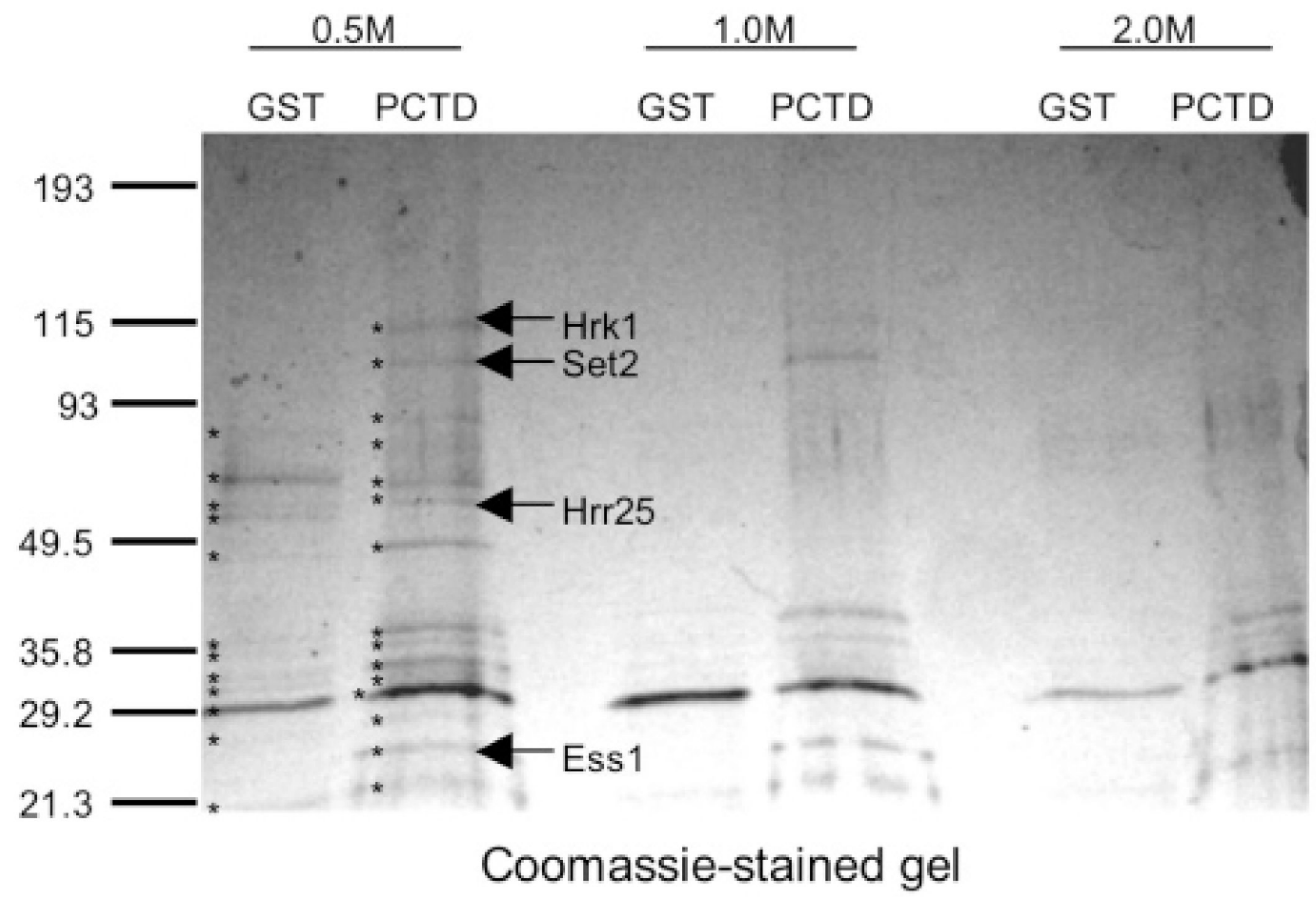

FIGURE 3.

Example of PCAP purification by method 2 (details in Materials and Methods). CM fractions were passed through a control GST column and then applied to a GST-PCTD affinity matrix. Both columns were eluted with salt steps, and the eluted proteins were analyzed by SDSPAGE. All stained bands (dots) were excised from the gel and analyzed by mass spectrometry. Proteins specifically eluted from the PCTD matrix are labeled. 


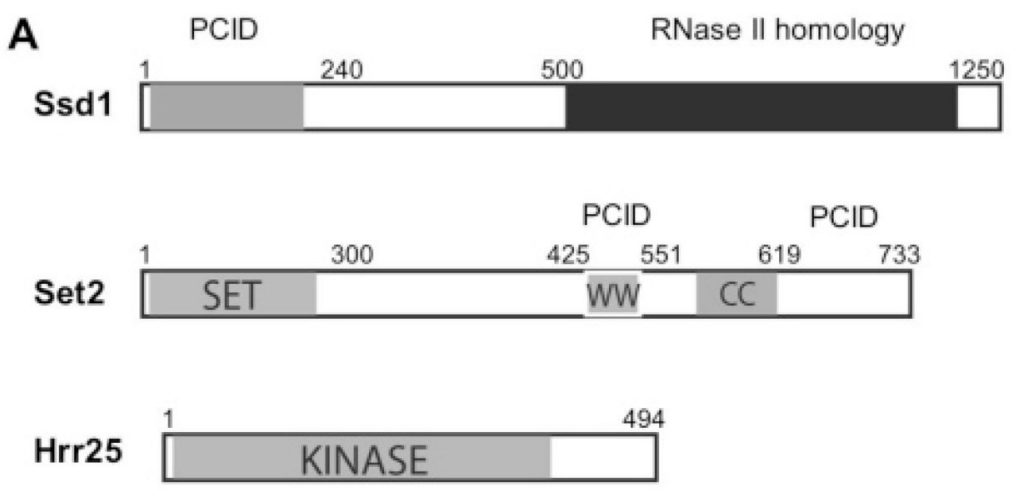

\section{Schematic representation of PCAPs}

B

\begin{tabular}{lllllll}
\multicolumn{4}{c}{ MBP-Ssd1 fragments } & MBP-Set2 \\
${ }_{1-500}$ & $1-240$ & $51-240$ & $91-240$ & $1-160$ & $501-1250$ &
\end{tabular}

$208-$
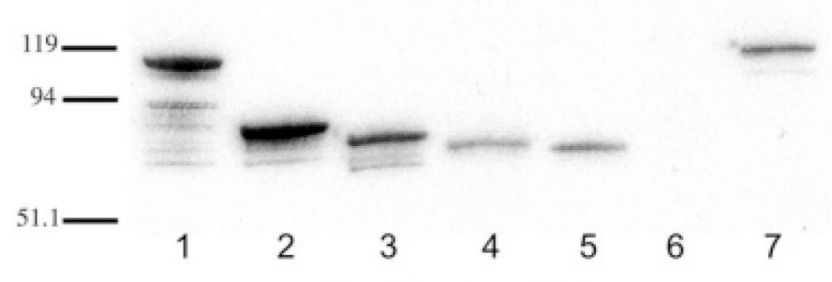

Far-Western Blot

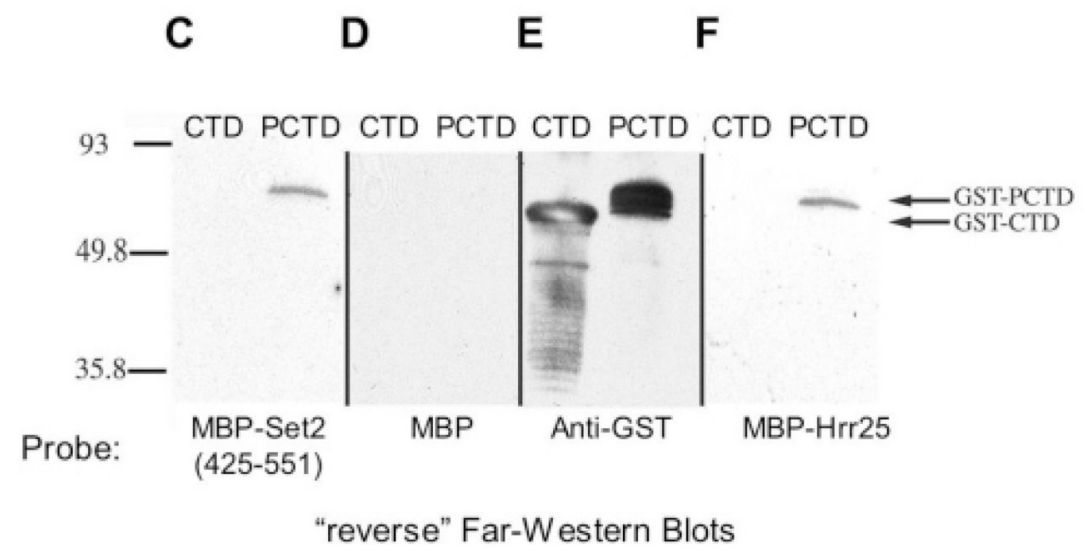

FIGURE 4.

A) Schematic representation of domain architecture of PCAPs Ssd1, Set2, and Hrr25. (B) Confirmation of the Ssd1- phosphoCTD interaction and identification of the binding domain. Fragments of Ssd 1 and Set 2 were expressed as recombinant MBP fusion proteins and analyzed by far-western blotting (amino acids defining the fragments are shown above their respective lanes). Approximately equal amounts of protein were run in each lane. The proteins were transferred to nitrocellulose and probed with GST-[ $\left.{ }^{32} \mathrm{P}\right] \mathrm{PCTD}$ fusion protein followed by autoradiography. (C) A second PCID in Set2. GST-CTD and GST-phosphoCTD were subjected to SDS-PAGE, transferred to nitrocellulose, and probed with purified recombinant MBP-Set2 (amino acids 425-551) in a reverse far-western assay. The MBP fusion protein was 
detected with an anti-MBP antibody. (D) Control: the blot in panel C was stripped and probed with purified recombinant MBP. (E) The blot in panel $F$ was stripped and probed with an antiGST antibody to demonstrate the presence of the GST-CTD fusion proteins. (F) Confirmation of the Hrr25-phosphoCTD interaction. A blot identical to the one in panel $\mathrm{C}$ was probed with purified recombinant MBP-Hrr25. The MBP fusion protein was detected with an anti-MBP antibody. 


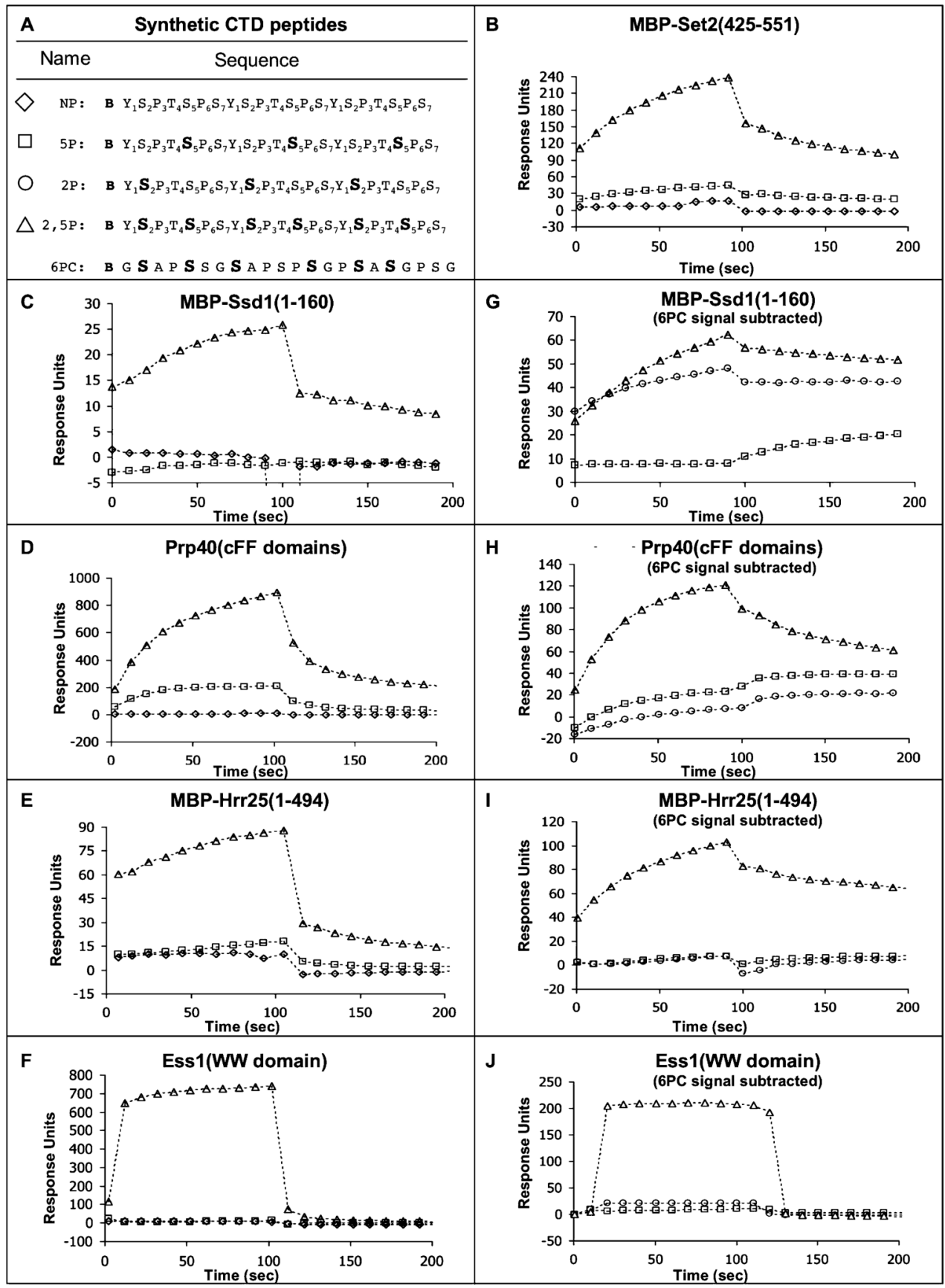

FIGURE 5.

Specificity of binding of various PCAPs to (phospho)CTD peptides using BIACORE (surface plasmon resonance) analysis. (A) Sequences of biotinylated peptides that were immobilized on streptavidin sensor chips with symbols used in graphs B-J. (B) Sensorgrams of binding of MBP-Set2(425-551) $(2 \mu \mathrm{M})$ to the 2,5P, 5P, and NP CTD peptides, after subtracting signal from an empty flow cell (nonspecific binding). (C) Sensorgrams of binding of MBP-Ssd1(1160) $(2 \mu \mathrm{M})$ to CTD peptides as in (B). (D) Sensorgrams of binding of Prp40 (cFF domains) [amino acids 267-583 (34)] (2 $\mu \mathrm{M})$ to CTD peptides as in (B). (E) Sensorgrams of binding of MBP-Hrr25(1-494) $(2 \mu \mathrm{M})$ to CTD peptides as in (B). (F) Sensorgrams of binding Ess1 (WW domain) $(2 \mu \mathrm{M})$ to CTD peptides as in (B). (G) Sensorgrams of binding of MBP-Ssd1(1-160) 
( $2 \mu \mathrm{M})$ to the 2,5P, 5P, and 2P CTD peptides, after subtracting signal from the scrambled 6PC peptide channel [sequences of peptides shown in (A)]. (H) Sensorgrams of binding of Prp40 (cFF domains) [amino acids 267-583 (34)] $(2 \mu \mathrm{M})$ to CTD peptides as in (G). (I) Sensorgrams of binding of MBP-Hrr25(1-494) $(2 \mu \mathrm{M})$ to CTD peptides as in (G). (J) Sensorgrams of binding of Ess1 (WW domain) $(2 \mu \mathrm{M})$ to CTD peptides as in (G). 


\section{CM16 on PCTD vs. 2,5P Peptide}

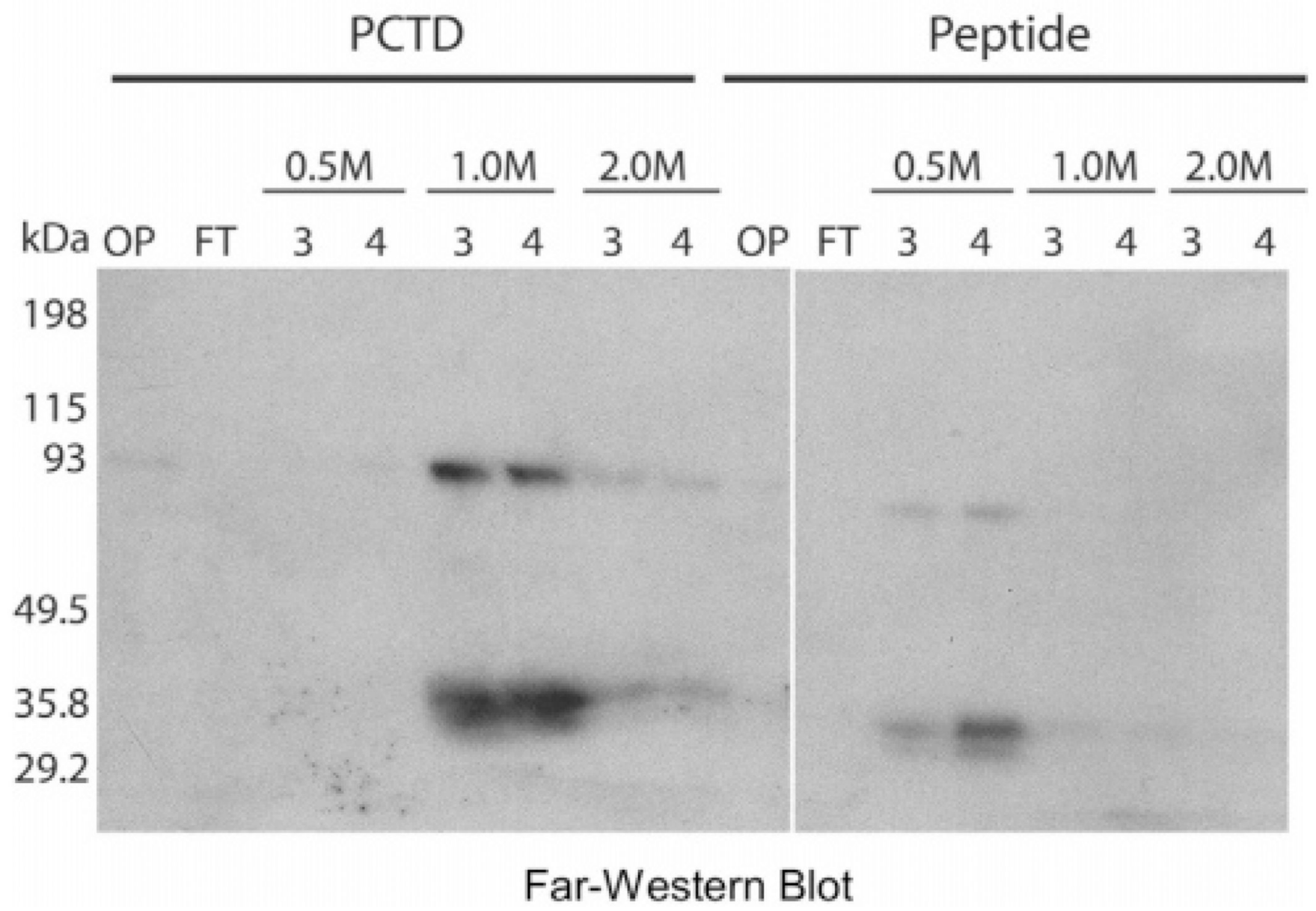

FIGURE 6.

Synthetic 2,5P peptide column mimics PCTD column. Each half of a CM fraction was subjected to affinity chromatography on either a PCTD matrix or a 2,5P peptide matrix. Both columns were eluted with salt steps and the eluted proteins analyzed by far-western blotting using GST- $\left[{ }^{32} \mathrm{P}\right] \mathrm{PCTD}$ as probe, followed by autoradiography. 

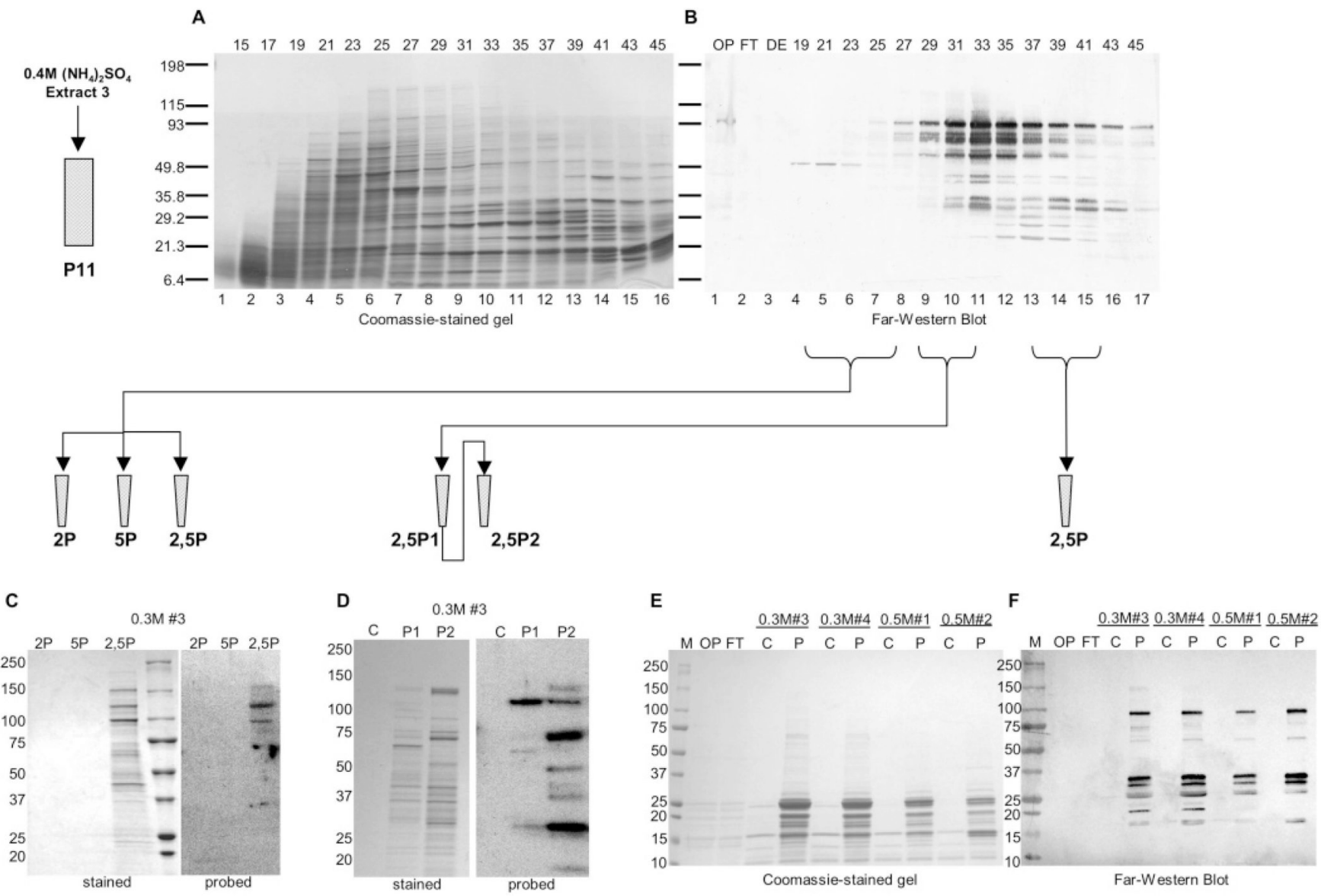

FIGURE 7.

PCAP purification by method 3. P11 fractions subjected to SDS-PAGE were stained with Coomassie Blue (A) or analyzed by far-western blotting (B) with GST-PCTD fusion protein as probe [OP ) onput, FT ) flow-through, DE ) proteins stepped off DEAE column with 0.35 $\mathrm{M} \mathrm{NaCl}$. (C) Pooled early P11 fractions were passed through a control (no peptide) column and then applied to either a $2 \mathrm{P}$, a 5P, or a 2,5P peptide column. Bound proteins were eluted with salt steps, electrophoresed in duplicate SDS gels, and either stained (Coomassie) or transferred to nitrocellulose and probed in a far-western blot with GST-[32P]PCTD as probe (0.3 M salt step fraction \#3 is shown; see Materials and Methods). (D) Pooled middle P11 fractions were passed through a control column and then applied to a lowconcentration 2,5P peptide column (P1; see Materials and Methods), and the flow-through was applied to a highconcentration 2,5P peptide column ( $\mathrm{P} 2)$. Bound proteins were eluted and analyzed as in (C). (E) Pooled late P11 fractions were passed through a control column and then applied to a 2,5P peptide column. Bound proteins were eluted and analyzed as in (C) except the GST-PCTD probe was detected by western blotting. Two fractions each of the 0.3 and $0.5 \mathrm{M}$ salt steps, as indicated, are shown. All stained bands from (C), (D), and (E) were excised and analyzed by mass spectrometry. Proteins so identified are listed in Figure 8. Symbols are as in Figure 1. 


\begin{tabular}{|c|c|}
\hline P11 early & P11 middle \\
\hline $\begin{array}{c}\text { Transcription } \\
\text { Cdc73, Ctr9, Ess1, Spt15 }\end{array}$ & $\begin{array}{c}\text { Transcription } \\
\text { Cka1, Ctr9, Hog1, Pho2, Rap1, } \\
\text { Spt15, Ume6 }\end{array}$ \\
\hline $\begin{array}{c}\text { RNA Processing } \\
\text { Emg1, Glc7, Kem1, Pus 1, Rai1, } \\
\text { Rat1, Reg2, Rrp5 }\end{array}$ & $\begin{array}{c}\text { RNA Processing } \\
\text { Cbp2, Enp1, Kem1, Mrt4, Rat1, } \\
\text { Rpf2, Utp20, Yra1 }\end{array}$ \\
\hline $\begin{array}{l}\text { Chromatin Structure } \\
\text { Gcn5, Isw1, Set2 }\end{array}$ & $\begin{array}{l}\text { Chromatin Structure } \\
\text { Has1, Nhp6a/b, Set2, Spt7 }\end{array}$ \\
\hline $\begin{array}{c}\text { DNA Metabolism } \\
\text { Hrr25, Stm1, Tah18, Top1 }\end{array}$ & $\begin{array}{c}\text { DNA Metabolism } \\
\text { Chl1, Pms1, Tah18, Top1, Ypr078c }\end{array}$ \\
\hline $\begin{array}{c}\text { Protein Synthesis \& Turnover } \\
\text { Cdc33, Mis1, Mrpl8, Trm8, Trm82, } \\
\text { Tys 1, Ygr054w, Zuo1 }\end{array}$ & $\begin{array}{l}\text { Protein Synthesis \& Turnover } \\
\text { Cic1, Fun12, Gcd10, Gcd14, Mis1, } \\
\text { Mrpl8, Sis1, Trm1, Tys1, Yjr070c }\end{array}$ \\
\hline $\begin{array}{c}\text { Other/Unknown } \\
\text { Abf2, Fox2, Msw1, Nfs1, Rvs161, } \\
\text { Vps16, Yil105c }\end{array}$ & $\begin{array}{c}\text { Other/Unknown } \\
\text { Fmt1, Osh2, Tes1, Ygr210c, } \\
\text { Ymr265c, Ypl260w }\end{array}$ \\
\hline
\end{tabular}

\begin{tabular}{|c|}
\hline P11 late \\
Transcription \\
Cka1, Cka2, Hsf1, Not5, Rtg2, \\
Ume6, Ypl133c \\
RNA Processing \\
Brx1, Cbf5, Cbp2, Ct11, Hca4, Rrp5, \\
Snu56, Ssd1, Ssf1, Ssf2, Tsr1, Vip1 \\
Chromatin Structure \\
Hat1, Hta1/2, Htb1/2, Htz1, Nnf1 \\
DNA Metabolism \\
Cdc14, Hrr25, Jem1, Tah18 \\
Protein Synthesis \& Turnover \\
Mrp7, Mrp18, Pus2, Ssb1, Ssb2, \\
Tef1, Tef2, Yer087w \\
Other/Unknown \\
Arh1, Mrp7, Myo3, Myo5, Noc2, \\
Osh2, Qri2, Sac1, Tes1, Ygr273c, \\
Yjr149w, Ylr455w, Ymr265c \\
\hline
\end{tabular}

FIGURE 8.

Proteins, from pooled P11 early, middle, and late fractions, affinity-purified on 2,5P peptide columns (see Figure 7 and Materials and Methods). 

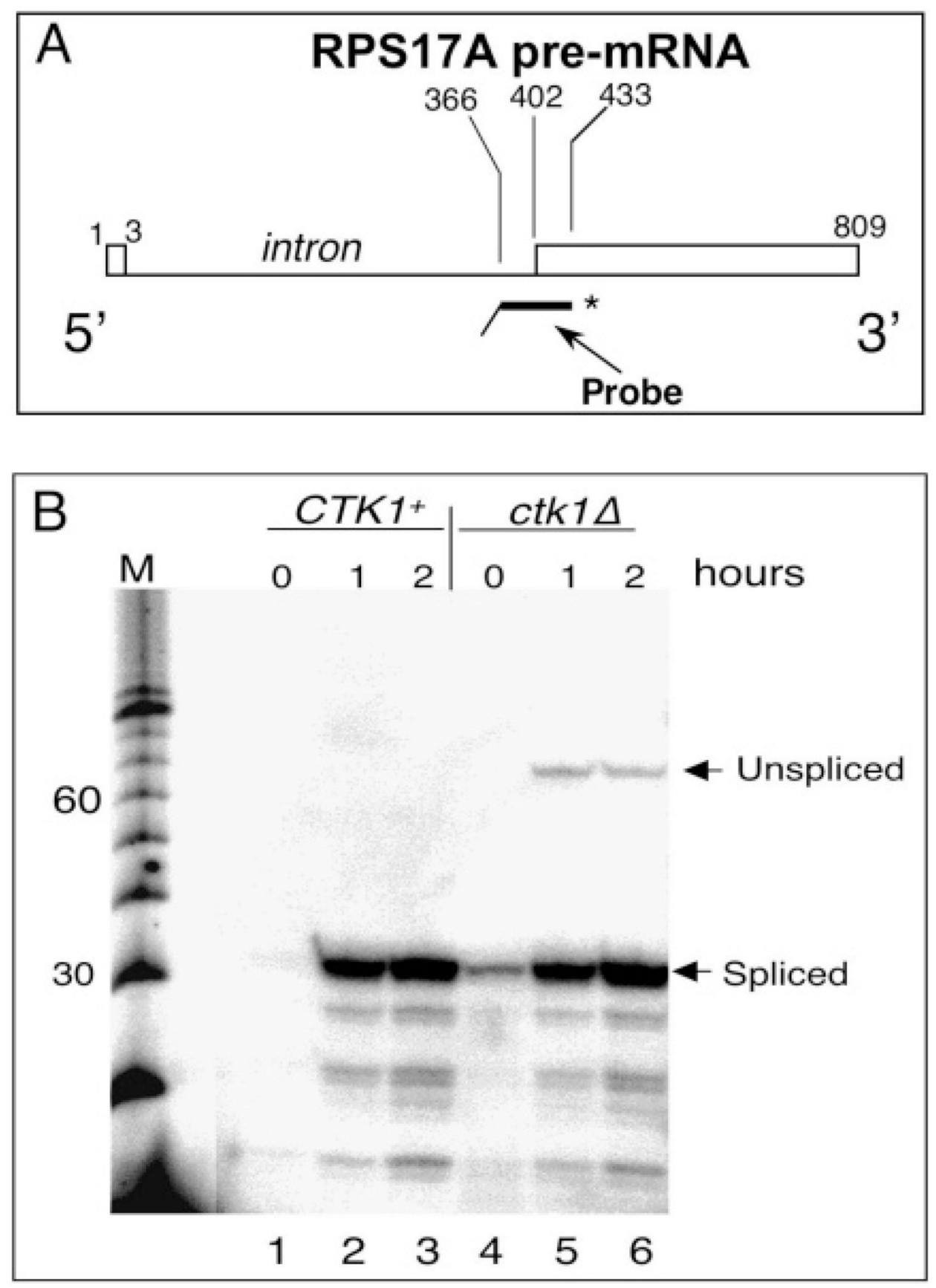

FIGURE 9.

Cells lacking CTDK-I are defective in splicing. (A) Diagram of the nuclease protection assay components; the asterisk indicates radiolabeled phosphate at the $5^{\prime}$ end of the probe. (B) Nuclease-protected RNA fragments were analyzed by denaturing PAGE and visualized by autoradiography. Size markers (M) are multiples of 10 nucleotides. Hours indicate time after return from starvation. 


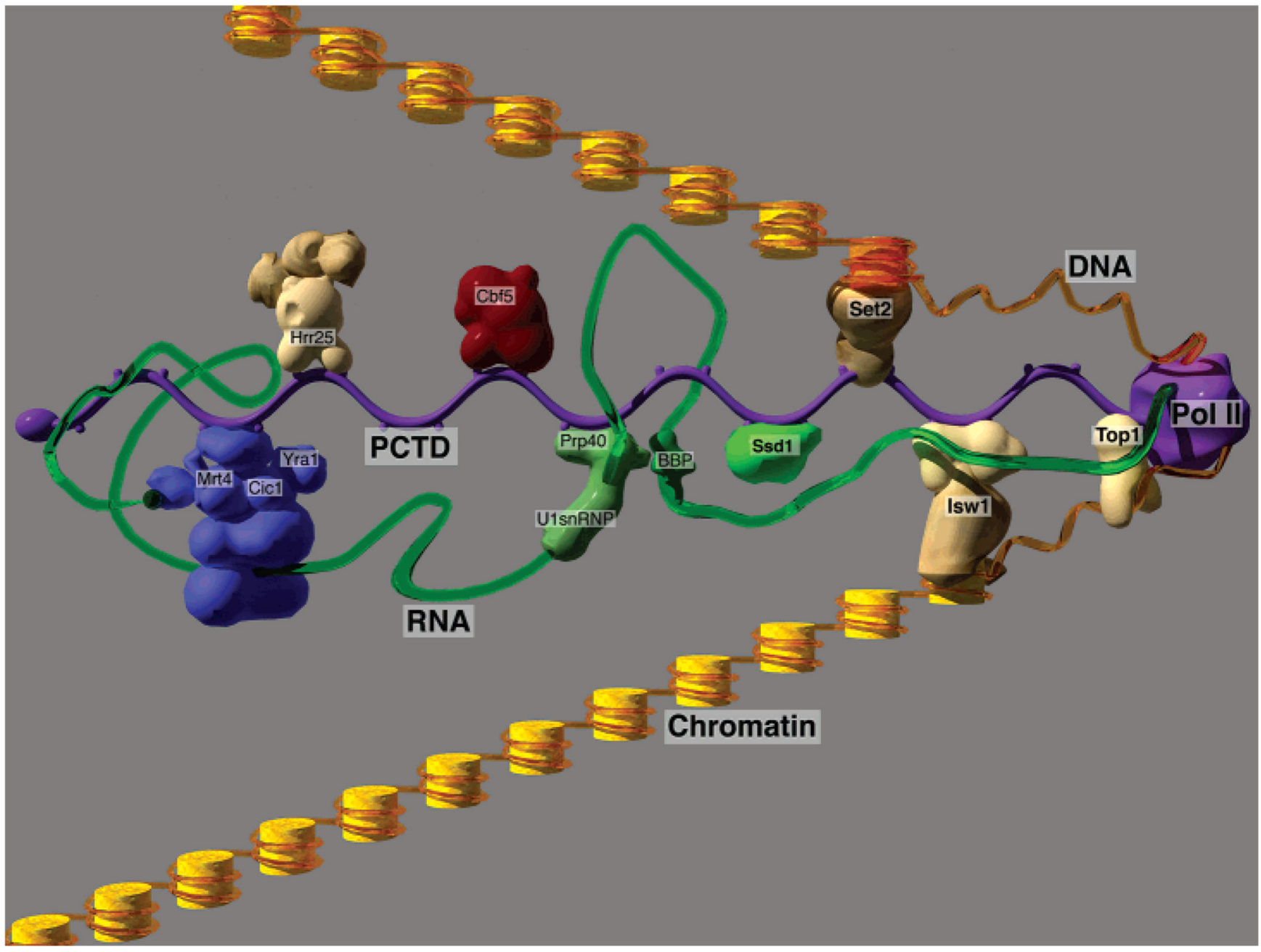

FIGURE 10.

Speculative model of PCAPs and associated proteins bound to the PCTD of elongating Pol II (see Discussion). 